\title{
Chagas' Disease
}

\author{
HERBERT B. TANOWITZ, ${ }^{1,2 *}$ LOUIS V. KIRCHHOFF, ${ }^{3}$ DOUGLAS SIMON, ${ }^{2}$ STEPHEN A. MORRIS, ${ }^{1,4}$ \\ LOUIS M. WEISS, ${ }^{1,2}$ AND MURRAY WITTNER ${ }^{1}$ \\ Departments of Pathology ${ }^{1}$ and Medicine, ${ }^{2}$ Albert Einstein College of Medicine, 1300 Morris Park Avenue, \\ Bronx, New York 10461; Department of Internal Medicine, University of Iowa, and the Department \\ of Veterans Affairs Medical Center, Iowa City, Iowa 522423; and Department of Medicine, \\ College of Physicians and Surgeons, Columbia University, New York, New York $10032^{4}$
}

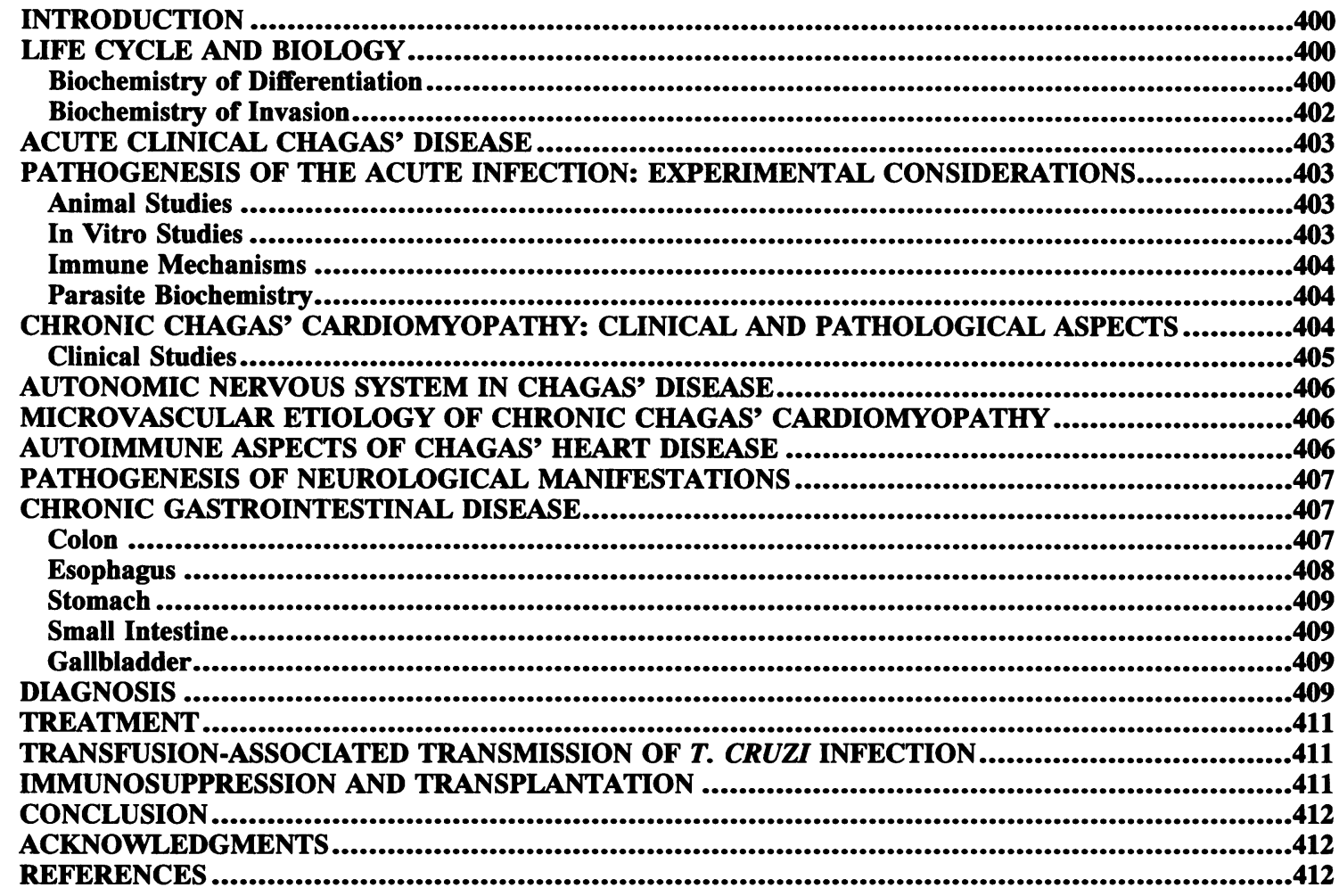

\section{INTRODUCTION}

Trypanosoma cruzi, the hemoflagellate protozoan that causes Chagas' disease, is an important cause of heart disease in Latin America (5). Approximately 10 to 20 million individuals are infected with this parasite, and 50,000 deaths annually are associated with the infection $(74,90)$. Chagas' disease has been found from the United States-Mexico border to Argentina and Chile. Despite the fact that $T$. cruzi has been found in insect vectors, dogs, and wild mammals in the southern part of the United States (22, 279, 281), autochthonous human cases have been reported rarely in the United States (176). In areas where the disease is endemic, it is most common among the rural poor, who live in an environment with many feral reservoir hosts. Although control programs directed at decreasing transmission of $T$. cruzi to humans by reducing vector populations have been successful in some areas of Latin America $(2,66)$, effective control measures are lacking in most regions of endemicity. A vaccine for preventing transmission of $T$. cruzi has not

\footnotetext{
* Corresponding author.
}

been developed despite considerable experimental work (123), and no chemoprophylactic drug is available.

Natural transmission of $T$. cruzi to humans is associated with the bite of the reduviid bug, which deposits excreta containing infectious metacyclic trypomastigotes that then contaminate the bite site and mucosal surfaces. Transmission via blood transfusion is common in areas of endemicity (234) and has been reported in the United States and Canada $(97,125,177)$. Chronic symptomatic cases of Chagas' disease have become evident as thousands of immigrants from South and Central America have moved to North America $(127,129)$. Congenital disease associated with premature birth, abortion, and placentitis has been reported from many areas of South America $(18,26)$. Breast feeding, organ transplantation, and laboratory accidents are less important modes of transmission $(30,90,110)$.

\section{LIFE CYCLE AND BIOLOGY}

Biochemistry of Difierentiation

In the complex life cycle of $T$. cruzi, at least three morphogenetic forms of the parasite can be recognized (Fig. 


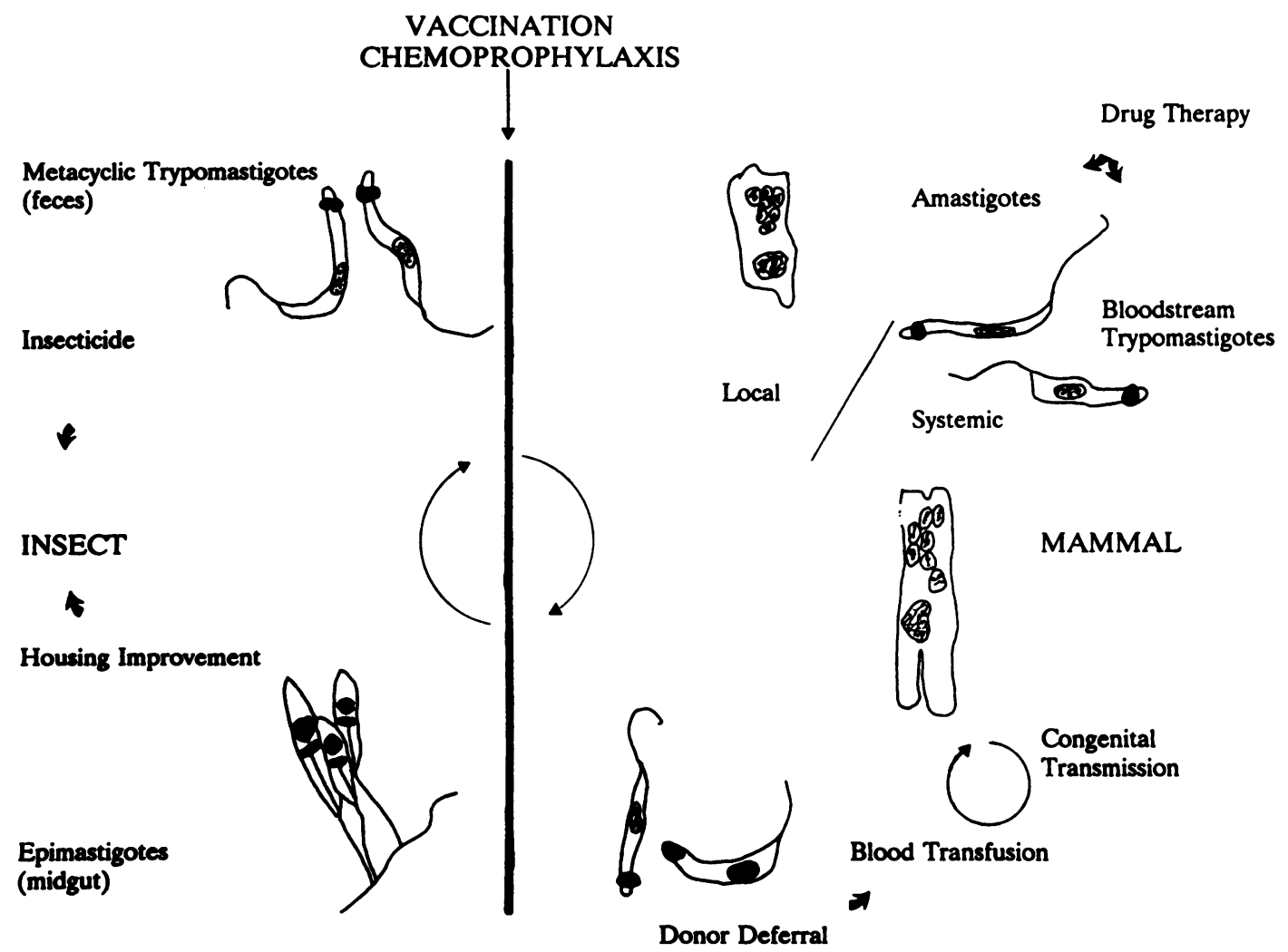

FIG. 1. Life cycle of $T$. cruzi. The parasites multiply as epimastigotes in the midgut of the insect vector. After transformation into metacyclic trypomastigotes, the organisms are deposited with the feces of the vector and infect mammalian cells in mucosal surfaces, conjunctiva, or breaks in the skin. Once inside the host cells, the parasites transform into amastigotes and, after several cycles of multiplication, transform again into bloodstream amastigotes, which are morphologically similar to the trypomastigotes present in insect feces. The host cell then ruptures, releasing the parasites into adjacent tissues and the circulation. The cycle is completed when circulating trypomastigotes are ingested in a blood meal taken by another insect vector and transform to epimastigotes in its midgut. The vertical arrow indicates the point at which the cycle could be broken by chemoprophylaxis or vaccination, neither of which has been developed yet. The short arrows indicate other points of intervention. Reprinted from reference 126 with the permission of Springer-Verlag.

1). Trypomastigotes (Fig. 2) (extracellular nondividing forms) and amastigotes (intracellular replicative forms) are found in mammalian hosts, whereas epimastigote forms divide in the midgut of reduviids. After the insect vector takes a blood meal containing trypomastigotes, the parasites transform into epimastigotes and multiply in the insect midgut. After 3 to 4 weeks, infective metacyclic trypomastigotes are present in the hindgut of the vector. The trypomastigotes are deposited during subsequent blood meals and may then enter new mammalian hosts. Trypomastigotes may be phagocytized by macrophages or may directly penetrate cells, where they transform into intracellular amastigotes.

Much of the information regarding metacyclogenesis has been obtained by using an in vitro culture system. Epimastigotes are inoculated into LIT medium (containing liver extract, various concentrations of fetal calf serum, tryptose, and hemin at $\left.26^{\circ} \mathrm{C}\right)(256)$, and, depending on the strain of $T$. cruzi used, various percentages of epimastigotes become metacyclic trypomastigotes. Several reports described a chemically defined synthetic medium, triatome insect urine, which contains buffer salts and a high concentration of L-proline (51). In this medium, high yields of metacyclic trypomastigotes can be obtained routinely. However, as with other media, the degree of transformation varies with the strain of $T$. cruzi. Regardless of the method used to induce metacyclogenesis, it appears necessary for the epimastigotes to be late in the exponential growth phase and to be present in medium depleted of nutrients.

In both the insect gut and defined medium, epimastigotes must adhere to the epithelium or substrate before they can undergo differentiation (28). However, adherence does not seem to be necessary for metacyclogenesis in LIT. Thus, adherence is not an absolute requirement for differentiation. Interestingly, it has been shown that metacyclogenesis is inhibited when GP-72 (a heavily glycosylated surface glycoprotein of epimastigotes and metacyclic trypomastigotes) reacts with a monoclonal antibody directed against this protein (236). These studies suggest that lectins present on cells of the reduviid gut may interact with GP-72, thus facilitating parasite surface adherence (193). The finding that cyclic AMP (cAMP) levels are significantly higher in trypomastigotes than in epimastigotes suggests that cAMP or its analogs stimulate metacyclogenesis $(96,205)$. In this parasite and in other systems, changes in cAMP levels are correlated with activation of protein kinases (111), gene transcription (106), and alterations in the cytoskeleton (62). How these affect metacyclogenesis remains to be determined.

Other important pathways in $T$. cruzi differentiation may include the many cell surface antigens that have been 


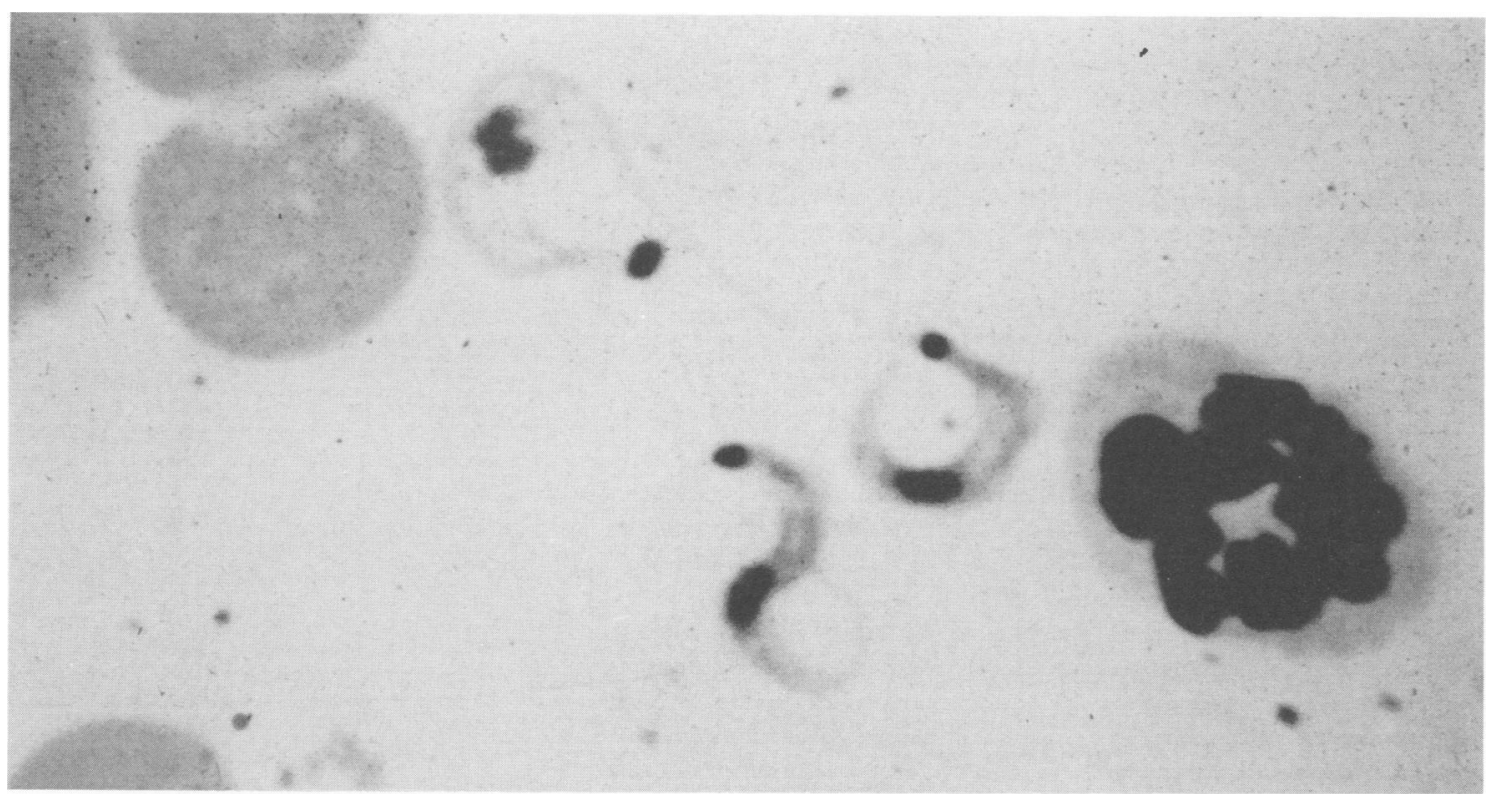

FIG. 2. Trypomastigotes in the peripheral blood. Reprinted with permission of the Armed Forces Institute of Pathology.

identified by monoclonal antibodies. Prominent among these various surface antigens are glycoproteins. Several of these glycoproteins are anchored to the surface membrane by a glycosyl-phosphatidylinositol linkage $(108,144,233)$ that has been shown to be sensitive to the action of phospholipase $\mathrm{C}$ in a specific manner (12).

The sensitivity of the differentiation process to external stimuli has stimulated interest in signal transduction pathways in the parasite per se. Thus, the demonstration of differentiation-specific fluctuations in the cAMP level has resulted in an analysis of the modulation of adenylate cyclase activity as well as the metabolism of cAMP. TellezInon et al. (268) have demonstrated the presence of a calmodulin-regulated cAMP-dependent phosphodiesterase. In related work with a calmodulin gel overlay procedure, the existence of stage-specific calmodulin-binding proteins in this parasite has been demonstrated (185). Their functional significance is under active investigation.

$\mathrm{G}$ proteins are guanine nucleotide-binding heterotrimeric proteins consisting of alpha, beta, and gamma subunits. They serve as coupling units between membrane-bound receptors and effector units such as adenylate cyclase or phospholipase $C$. There are reports that $G$ proteins, with characteristics similar to those of proteins known to participate in hormonally regulated signal transduction systems in higher eukaryotes, are present in $T$. cruzi (72). However, it has not been established that these $G$ proteins participate in an identical manner in this parasite. Another potential second messenger in this parasite is calcium. Cytosolic calcium concentrations ranging from 60 to $150 \mathrm{nM}$ are maintained despite extracellular calcium concentrations of $5 \mathrm{mM}$ (188). The presence of active sequestration processes in the endoplasmic reticulum and mitochondria with similarities to processes observed in higher eukaryotic organisms has been documented (275). The relationship of calcium to the recently described inositol phosphate-diacylglycerol pathway and its possible role in differentiation remain to be elucidated (68).

\section{Biochemistry of Invasion}

In addition to the interest in the biochemistry of parasite differentiation, there has been an increasing focus on the invasion process. Trypomastigotes are refractory to complement-mediated lysis, whereas epimastigotes activate the alternate complement pathway. The mechanism of the resistance of trypomastigotes to complement is unclear, and several different mechanisms have been proposed $(104,114$, $115,235)$. Amastigotes activate complement but are not lysed. Trypomastigotes bind small amounts of $\mathrm{C} 3$ but can infect cells that do not have receptors for C3 fragments. Other host cell surface molecules may be important in the process of entry. In this regard, it has been suggested that fibronectin increases the internalization of trypomastigotes in both phagocytic and nonphagocytic cells (53) and may act as a bridge to facilitate the attachment of the parasite to the target host cell (104).

Host cell entry by the parasite is a complex process involving a variety of factors (216). Schenkman et al. (229) have shown that trypomastigotes enter cells in a polarized manner preferentially along the basolateral membrane, where fibronectin and host cell receptors are concentrated. Invasion is an active process associated with factors such as parasite energy and host cell protein synthesis (232). Parasite phospholipase $\mathrm{A}_{2}$ has also been implicated in this process (49). A $T$. cruzi trans-sialidase has been shown to facilitate the generation of a trypomastigote-specific epitope, Ssp-3, that is required for invasion (231). Recently, Ortega-Barria and Pereira have found a $60-\mathrm{kDa} T$. cruzi surface protein (penetrin) that promotes adhesion and invasion into host cells (186).

The entry of trypomastigotes into host cells has not been reported to be associated with a respiratory burst, suggesting that nonoxidative intracellular mechanisms may be important in limiting intracellular infection (151). Within the parasitophorous vacuole, parasites may be killed by cytocidal mechanisms such as production of hydrogen peroxide. This process may be associated with lysosomal fusion $(247,256)$. 
The participation of nitric oxide in the intracellular killing of this parasite has recently been reported (174).

Trypomastigotes and amastigotes synthesize a hemolytic protein that is optimally active at acid $\mathrm{pH}$ and is capable of lysing the membrane of the parasitophorous vacuole (11). Liberated organisms are now left free to lie in the host cell cytoplasm and multiply by binary fission. Host cells distended with organisms rupture and release amastigotes and trypomastigotes, both of which may infect adjacent or distant uninfected cells. Rosenberg et al. (222) have suggested that neuraminidase associated with intracellular trypomastigotes may play a role in the exit of parasites from host cells. Trypomastigotes also enter the bloodstream and infect distant tissues. Although no tissue is spared from infection, strains may vary in tropism (29); the reticuloendothelial and nervous systems (especially the autonomic ganglia) and striated and cardiac muscles seem to be particularly vulnerable.

\section{ACUTE CLINICAL CHAGAS' DISEASE}

At the site of parasite entry, an inflammatory lesion, known as a chagoma, may develop. The inflammatory process spreads regionally, and focal lymphadenopathy may be evident. Asynchronous cycles of parasite multiplication, cell destruction, and reinfection occur within cells of the reticuloendothelial system. Most persons with acute Chagas' disease have only mild symptoms. However, children and, less frequently, adults may develop severe symptoms after an incubation period of 7 to 14 days. These symptoms include unilateral painless periorbital edema (Romaña's sign) and conjunctivitis. Other manifestations may include fever, lymphadenopathy, hepatosplenomegaly, nausea, vomiting, diarrhea, rash, anorexia, lassitude, and meningeal irritation.

A small number of patients with acute Chagas' disease develop severe myocarditis. Foci of myocytolytic necrosis, degeneration accompanied by inflammatory cells, and parasitism of the myofibers may be evident. A mixed inflammatory exudate with polymorphonuclear leukocytes, mononuclear cells, and pseudocysts containing amastigotes can be found interspersed among the degenerating fibers. In the mouse model, eosinophils have also been demonstrated (159), but their relevance to human disease is unclear.

Myocarditis may be clinically evident and may include tachycardia, congestive heart failure, and cardiomegaly $(206,215,237)$. In some patients, the electrocardiogram (ECG) may reveal prolongation of the P-R interval, nonspecific $\mathrm{T}$-wave changes, and low voltage. The appearance of arrhythmias, heart block, or progressive congestive heart failure during the early phase of acute Chagas' disease is an indicator of a poor prognosis. The presence or severity of acute myocarditis may not be related to the subsequent development of chronic chagasic cardiomyopathy, but this has not been studied prospectively.

Trypomastigotes are found in the peripheral blood and also in the cerebrospinal fluid in patients with acute infection (109). Anemia, thrombocytopenia, leukocytosis with a lymphocyte predominance, abnormal liver function, and elevated cardiac enzyme levels are among the common laboratory abnormalities reported.

A small percentage of individuals with acute disease die of complications associated with acute myocarditis or meningoencephalitis. However, exact numbers are difficult to obtain. It is important to note that most patients with acute disease recover completely within 3 to 4 months and that most are unaware of having an acute illness. In those who die during the acute phase, amastigotes are easily demonstrated in cardiac, skeletal, and smooth muscle cells as well as glial cells.

\section{PATHOGENESIS OF THE ACUTE INFECTION: EXPERIMENTAL CONSIDERATIONS}

\section{Animal Studies}

In experimental disease, several biochemical alterations of the myocardium have been reported to be related to the development of chronic cardiomyopathy. For example, reductions in the levels of choline acetyltransferase (250), acetylcholine (146), norepinephrine (147), and the $\beta$-adrenergic adenylate cyclase complex $(164,168)$ of cardiac tissue have been reported in animal models. In many instances, biochemical abnormalities precede morphological changes.

Some morphological changes during acute infection may have implications for the pathogenesis of chronic chagasic cardiomyopathy. For example, the destruction of autonomic ganglia may have profound implications not only for the development of heart disease but also for gastrointestinal involvement. In addition, we have shown that during acute murine disease, endothelial cells lining the coronary vasculature are infected and may be associated with focal alterations in the coronary microvasculature, increased platelet aggregation, and adherence (249).

\section{In Vitro Studies}

During acute infection, pathological damage is correlated with the presence of parasites. In this regard, the effect of infection on muscle cell function has been studied. It has been shown that in infected myoblasts there is a reduction in the amount of muscle-specific mRNAs (myosin heavy chain and $\alpha$-actin) which is associated with inhibition of differentiation to myotubes (224).

Another aspect of cell metabolism that is disrupted by infection is the response of a cell to external stimuli, including signal transduction mechanisms. Infection is associated with alterations in $G$ protein-mediated functions. In this regard, perturbations in the generation of cAMP in myoblasts (166) and endothelial cells (169) have been demonstrated. In addition, the generation of cAMP in response to hormonal stimulation is significantly reduced in infected cells by virtue of an increase in endogenous phosphodiesterase. There are also infection-associated changes in the intracellular mobilization of calcium $(165,167)$ and the production of prostacyclin (249). Infection-associated perturbations in endothelial-cell signal transduction mechanisms may contribute to focal abnormalities, which may include the coronary microvascular spasm reported in acute murine infection (75). The focal pathological changes seen in human Chagas' cardiomyopathy have led to speculation that these are also partially due to coronary microvascular spasm (223).

In vitro biochemical studies have demonstrated that $T$. cruzi infection-associated perturbations are not related to the percentage of parasitism in the culture. To explore the effect of host cell infection on adjacent uninfected cells, the influence of the extracellular matrix (ECM) was studied. Infection of endothelial cell cultures alters their synthetic capabilities. For example, sulfation of glycosaminoglycan side chains of heparan sulfate proteoglycans deposited in the ECM of endothelial cells was increased after infection (171). Further, when uninfected endothelial cells were grown on 
the ECM deposited by infected endothelial cells, the uninfected endothelial cells produced ECM identical to that synthesized by infected endothelial cells, suggesting that the signals responsible for directing the synthesis of this altered proteoglycan resided in the ECM. These studies provide a basis for the notion that a few infected cells can influence larger numbers of uninfected cells in a cumulative response via the ECM (171).

To investigate further the influence of infected host cells on uninfected cells, the involvement of host cell gap junctions was studied. T. cruzi infection of rat neonatal cardiocytes altered the spread of the contractile wave. This observation was associated with reduced gap junction abundance and function as determined by various parameters such as dye coupling, junctional conductance, and immunocytochemical studies (39). More recently, decreased concentrations of gap junction protein in infected murine hearts have been demonstrated (unpublished observations). These alterations in intercellular communication may provide a cellular basis for the conduction disorders associated with Chagas' disease.

\section{Immune Mechanisms}

Immune mechanisms may participate in the pathogenesis of Chagas' disease. The immunology of this infection in both animal models and humans has been studied extensively over the past two decades. There is evidence from the mouse model that both humoral and cell-mediated components of the immune system are important in host resistance, as is the genetic background (124). A recent development is the work by Tarleton et al. $(259,261)$ regarding the role of $\mathrm{CD}^{+} \mathrm{T}$ cells in the pathogenesis of this infection. Infected mice depleted of $\mathrm{CD}^{+}$cells by antibody treatment and $\beta_{2^{-}}$ microglobulin-deficient mice, which lack mature $\mathrm{CD}^{+} \mathrm{T}$ cells, experience high parasitemia and early death. Additionally, parasitized tissues lack an inflammatory response. Since the development of natural killer cells is also impaired in $\beta_{2}$-microglobulin-deficient mice, more precise delineation of the cell types involved in these observations awaits further experiments. In this regard it is of interest that Ben Younes-Chennoufi et al. (23) have shown that most of the T cells infiltrating the heart in the course of experimental infection are $\mathrm{CD} 4^{+} \mathrm{T}$ cells.

In recent years, the role of cytokines in the pathogenesis of $T$. cruzi infections has been the subject of intense investigation. Both humoral and cellular immunities are suppressed in experimental infections, and altered interleukin 2 (IL-2) concentrations are associated with this immunosuppressed state $(257,262,263)$. Furthermore, it has been suggested that IL-2 may participate in disease-related autoimmune phenomena in mice (262). In addition, tumor necrosis factor alpha, IL-5, and gamma interferon (IFN- $\gamma$ ) levels may be elevated during acute murine infection and may contribute to the pathogenesis of the disease $(258,260)$. More recently, $T$. cruzi-infected human peripheral blood monocytes and endothelial cells have been shown to synthesize increased levels of IL-1 $\beta$ and IL-6 $(252,273)$. Increased levels of IL-1, tumor necrosis factor, and IL-6 were reported to cause alterations in human endothelial cell function such as leukocyte recruitment $(25)$, coagulation $(92,175)$, and smooth muscle proliferation (139), which may have important implications for the pathogenesis of Chagas' disease.

IFN- $\gamma$ and granulocyte-macrophage colony-stimulating factor have been reported to ameliorate the consequences of experimental murine $T$. cruzi infections $(207,208)$. With these experimental results in mind, two patients with acute Chagas' disease have been treated with IFN- $\gamma$ as adjunct therapy to nifurtimox treatment $(97,252)$. A possible biochemical mechanism by which these cytokines exert protective effects during infection is suggested by recent results showing that cytokines such as IFN- $\gamma(95,207,238,282)$ enhance intracellular killing of $T$. cruzi both in vitro and in the murine model.

\section{Parasite Biochemistry}

The biochemistry of the parasite itself may contribute to the pathogenesis of the disease. In this regard it has recently been reported that trypanosomes contain a variety of enzymes such as proteases, gelatinases, and collagenases that are capable of degrading native type I collagen, heat-denatured type I collagen (gelatin), and native type IV collagen $(42,78,98)$. Proteolytic activities against laminin and fibronectin were also detected. These enzymes may play an important role in the degradation of the ECM and the subsequent tissue invasion by the parasite. It has been proposed that degradation of the collagen matrix, evident in acute murine Chagas' disease, may result in chronic pathologic changes such as apical thinning $(77,182)$. Finally, supernatants obtained from cultures of infected fibroblasts, vascular smooth muscle cells, and myocardial cells were found to stimulate fibroblast DNA and protein synthesis as well as proliferation, whereas supernatants from uninfected cells did not. This suggests a mechanism by which fibrosis may occur in chronic chagasic cardiomyopathy (284).

Other parasite enzymes may cause cell and tissue damage. For example, trypomastigotes elaborate a developmentally regulated neuraminidase $(192,193)$ that removes sialic acid from the surface of cardiac and endothelial cells (138). The loss of sialic acid from cardiocytes alters intracellular calcium homeostasis and ultimately myocardial function (83). The relationship between this enzyme and $T$. cruzi transsialidase has recently been investigated (230).

$T$. cruzi neuraminidase is inhibited by anti-neuraminidase antibodies and high-density lipoprotein, which is associated with enhanced infectivity of cells in vitro $(202,203)$. The significance of these observations in the pathogenesis of Chagas' disease is unclear. However, it is noteworthy that mice with higher levels of high-density lipoprotein are more susceptible to $T$. cruzi infection (202). The relationship between the synthesis of these parasite enzymes and the pathogenesis of the disease remains to be elucidated.

\section{CHRONIC CHAGAS' CARDIOMYOPATHY: CLINICAL AND PATHOLOGICAL ASPECTS}

Chronic Chagas' disease may present with arrhythmias, thromboembolic events (181), or congestive heart failure. Dilated congestive cardiomyopathy is an important manifestation of chronic Chagas' disease that occurs years after acute infection. Apical aneurysm is usually found in the left ventricle (182) (Fig. 3 and 4).

Myocardial infarction has been reported (64) and is thought to be due to embolization from a left apical aneurysm. Arteriosclerosis and necrotizing arteriolitis have been described $(178,179,270)$. Most cases of myocardial infarction occur in the presence of normal coronary arteries (24, 149). Vasculitis of the coronary microvasculature occurs in a canine model of Chagas' disease (21).

Chronic Chagas' disease may be accompanied by myonecrosis, myocytolysis, and contraction band necrosis. Focal 


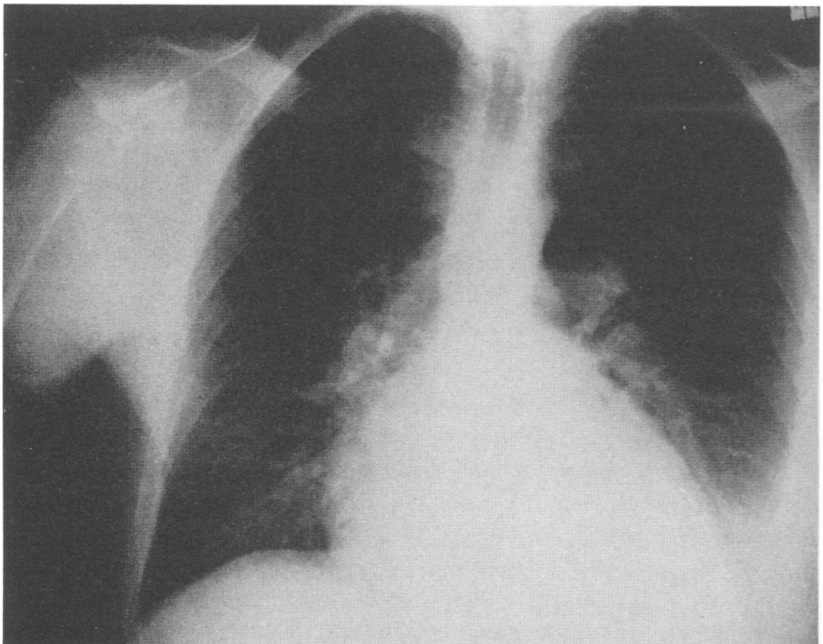

FIG. 3. Chest $\mathrm{X}$ ray of a patient with Chagas' cardiomyopathy. Note the cardiomegaly and pulmonary vascular congestion and an epicardial pacemaker.

and diffuse areas of myocellular hypertrophy with or without inflammatory infiltrates may be seen. In addition, focal fibrosis replacing previously damaged myocardial tissue is evident. It has been reported (7) that collagenolysis and invasion by macrophages may be evident. All areas of the heart, including the conduction pathways, may be damaged (9), resulting in conduction disturbances (10); microvascular involvement has been demonstrated (79).

\section{Clinical Studies}

The electrophysiological, echocardiographic, and angiographic alterations that accompany chronic Chagas' disease have been extensively studied $(105,136,221)$. Destruction of conduction tissue results in atrioventricular and intraventricular conduction abnormalities. In areas where the disease is endemic, the presence of right bundle branch block associated with an anterior fascicular block is suggestive of cardiomyopathy. Extrasystoles and first-degree heart block are common, whereas atrial fibrillation and left bundle branch block are reported to be uncommon. However, a recent study suggests that atrial fibrillation may be more common than was previously appreciated (103). Conduction defects may necessitate the placement of a pacemaker (45).

Zicker et al. (285) have shown that asymptomatic seropositive individuals have a much higher prevalence of ECG abnormalities than do uninfected persons. The progressive development of ECG abnormalities, notably right bundle branch block and left anterior hemiblock, was demonstrated in a prospective study of 1,051 persons in an area of endemicity in Brazil (148). The results of that study suggested that in seropositive individuals with right bundle branch block occurring in combination with anterior fascicular block or ventricular extrasystoles, the mortality rate was significantly higher than in seropositive persons with normal ECGs. Sinus node dysfunction was demonstrated in 8 of 44 asymptomatic seropositive individuals with normal chest X rays and ECGs (199). During incremental or programmed atrial pacing, 14 patients demonstrated atrioventricular node conduction disturbances. Eighteen of these asymptomatic patients demonstrated repetitive ventricular responses to single ventricular premature beats, showing an

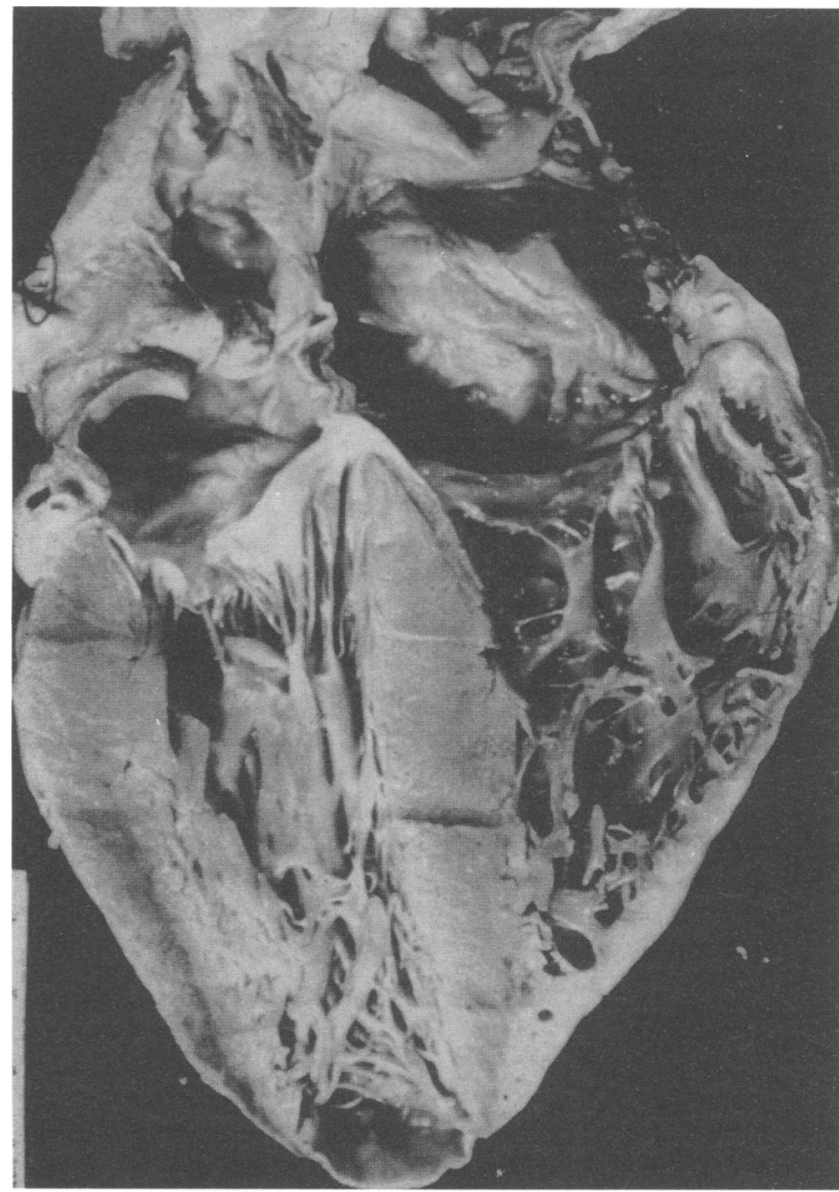

FIG. 4. Chagas' cardiomyopathy. The heart is dilated and hypertrophied, and there is an apical aneurysm. Reprinted with permission of the Armed Forces Institute of Pathology.

early predisposition to ventricular arrhythmias, which is consistent with the clinical impression that patients with chronic cardiomyopathy are prone to ventricular arrhythmias. Casado et al. (41) have suggested that chagasic patients with arrhythmias and left ventricular conduction defects had the largest left ventricular volumes. Additionally, their data suggest that during late-stage disease, when there are several significant ECG abnormalities, there is an increase in the left ventricular volume and a decrease in the ejection fraction. However, it has been difficult to determine which of the many electrophysiological abnormalities predict progression to severe cardiomyopathy.

Asymptomatic seropositive individuals often have left ventricular abnormalities demonstrable by cineangiographic and radionucleotide studies $(15,40)$. Forty percent of seropositive individuals without clinical, ECG, or radiological evidence of heart disease demonstrated apical or anterior apical asynergy, whereas $98 \%$ of seropositive individuals with abnormal ECG findings demonstrated extensive asynergy, left ventricular dilatation, decreased distensibility, and depressed contractility (40). Patients with both ECG abnormalities and heart failure were older, and their left ventricle was dilated and hypokinetic, with large apical aneurysms and thrombosis. This study also established that many clinically asymptomatic individuals had myocardial dysfunction. An earlier autopsy study of more than 5,000 patients 
with Chagas' disease (182) demonstrated no relation between age, duration of disease, and presence of an aneurysm. A similar study found that the incidence of abnormal biopsies was greater in asymptomatic patients with abnormal ECG or radiological findings. Myocardial hypertrophy and fibrosis, but not inflammation, correlated best with the severity of cardiac symptoms (194).

More recently, Guerra et al. (100) studied asymptomatic individuals with normal ECGs and no hemodynamic or cineangiographic evidence of heart disease and asymptomatic individuals with normal ECGs but with evidence of segmental myocardial damage demonstrated by cineangiography. A $60 \%$ incidence of microscopic abnormalities was seen in the former group, whereas alterations in the contractile system were more prominent in the latter group. Consistent with microvascular involvement, extensive basement membrane thickening was noted (79). Recently, de Paola et al. (65) demonstrated the association between conduction disturbances, angiographic evidence of left ventricular aneurysms, and development of sustained ventricular arrhythmias.

Echocardiographic studies $(33,48)$ have shown that 10 to $15 \%$ of asymptomatic individuals have apical dyskinesia. Right ventricular aneurysms have been found by echocardiography to occur in $10 \%$ of cases. Echocardiography may reveal thrombi at the apical aneurysm. Apical aneurysm in asymptomatic seropositive individuals is rare. A study of asymptomatic seropositive patients with and without abnormal ECGs and chest $X$ rays revealed significant abnormalities in diastolic and systolic functions, including delayed closure of the aortic valve, delayed opening of the mitral valve, and prolonged isovolemic relaxation. Abnormalities during isovolemic contraction and the early relaxation phase were ascribed to asynchronous onset of contraction, not dissimilar from what occurs in patients with ischemic heart disease of other causes (3).

Collectively, these clinical studies suggest that Chagas' cardiomyopathy results from a progressive, focal compromise in the integrity of both the myocardium and the conduction system. The association of right bundle branch block, left anterior hemiblock, and left ventricular apical aneurysm suggests that focal abnormalities may be regionally selective. Although inflammatory cells are associated with myocytolysis, their variable presence and poor correlation in biopsy studies make their etiologic role in pathogenesis questionable.

\section{AUTONOMIC NERVOUS SYSTEM IN CHAGAS' DISEASE}

The autonomic nervous system dysfunction associated with $T$. cruzi infection has been studied in order to understand the clinical manifestations of chronic disease (255). The depletion of cardiac acetylcholine and choline acetyltransferase seen in experimental animals $(146,250)$ could adversely affect parasympathetic nervous system function. In this regard, it was recently reported that depolarization-induced acetylcholine overflow was significantly reduced in atria from $T$. cruzi-infected rats with electrocardiographically characterized cardiopathy (81).

Dysfunction of the autonomic nervous system led to the hypothesis that Chagas' cardiomyopathy may be caused by autonomic neuronal damage to the heart $(101,180,183)$. Results of studies demonstrating destruction of cardiac ganglia also support this hypothesis (250); however, variability (61) in the density of myocardial vagal ganglia has been reported. Vagal denervation has been observed in dilated cardiomyopathies of other causes (6); therefore, its association with advanced Chagas' disease may not imply a primary pathogenic role. Of note is that alterations in parasympathetic function in seropositive patients antedate the onset of clinically significant myocardial dysfunction (89). Abnormalities in the sympathetic component of the autonomic nervous system in chagasic patients, as reflected in the apparent reduction in levels of plasma norepinephrine (112), and a reduction in diastolic blood pressure in the upright position have been reported.

\section{MICROVASCULAR ETIOLOGY OF CHRONIC CHAGAS' CARDIOMYOPATHY}

The notion that the cardiomyopathy of Chagas' disease may be the result of changes in the coronary microvasculature is not new; recently it has received increasing attention $(75,223)$. This mechanism is thought to be the case in cardiomyopathies of other causes (76). Indeed, focal microvascular spasm and microaneurysm formation during the course of acute murine infection with $T$. cruzi have been described (75). In infected mice, verapamil ameliorated the pathological and biochemical alterations associated with both acute and chronic infections. This was believed to be partly due to an increased or sustained coronary perfusion $(170,254)$. In addition, reports that platelet thrombi were found within the coronary microvasculature of infected mice led to investigations that might explain the compromise in vascular perfusion that was observed. To this end, increased platelet reactivity during acute infection, which could contribute to platelet thrombosis, has been demonstrated (249). A possible explanation for these observations is that the interaction between platelets and damaged endothelium or subendothelial surfaces can stimulate the activation of platelets, with subsequent generation of thromboxane $A_{2}$ and possibly platelet-derived growth factor. Elevated levels of thromboxane $\mathrm{A}_{2}$ in the plasma of acutely infected mice may contribute to increased intravascular platelet aggregation and focal microvascular spasm. In addition, during acute infection, the parasitism of the endothelial cells lining the coronary microvasculature may cause alterations in the generation of intracellular second messengers that may contribute to diminished microvasculature perfusion. Recent studies by Marin-Neto et al. (149) on humans and those in our laboratory on mice (253) demonstrated that in Chagas' disease there is decreased cardiac perfusion.

Inflammatory cells may also contribute to a state of microvascular hypoperfusion (280) by secretion of cytokines and other factors known to influence platelets and endothelial cells (see the section on immune mechanisms, above). In addition, $T$. cruzi infection of endothelial cells results in increased mRNA for IL-1 $\beta$ and IL-6 and a significant increase in the synthesis of these vasoactive proteins (252). It is likely that damage to the microcirculation leads to pathological changes that are essentially identical to those seen in diseases that involve primarily the coronary microcirculation.

\section{AUTOIMMUNE ASPECTS OF CHAGAS' HEART DISEASE}

Chronic chagasic cardiomyopathy is generally accompanied by few if any organisms, which has engendered the notion that the pathogenesis has an autoimmune etiology $(215,227)$. This was originally based on the observation that 
an antibody that reacted with endothelium and vascular and interstitial structures was present in sera of patients with chagasic heart disease (54). However, this concept was subsequently modified (119). Cardiac lesions following the transfer of parasite-sensitized lymphocytes have been reported (267), and lymphocytes from patients with Chagas' disease destroyed normal heart cells (266). Moreover, spleen cells from infected mice were cytotoxic for normal syngeneic neonatal cardiac muscle (1). Recently, Rizzo et al. (218) reported that $\mathrm{CD}^{+} \mathrm{T}$ cells from chronically infected mice proliferate in response to myosin. A cross-reacting antibody to a $25-\mathrm{kDa} T$. cruzi polypeptide has been found in sera of patients with primary muscle disease or advanced Chagas' cardiomyopathy (228). Sadigursky et al. (225) reported a cross-reacting antigen shared by $T$. cruzi and muscle sarcoplasma reticulum. Circulating antibodies to a variety of antigens have also been reported. For example, Szarfman et al. (246) have described antibodies to laminin and Mesri et al. (158) recently found anti-P autoantibodies in patients with Chagas' disease. Murine Chagas' disease has been associated with the presence of antiheart autoantibodies (152). Recent observations suggest that autoimmunity is an important mechanism in the rejection of syngeneic heart tissue grafted into the pinna of the ear of chronically infected mice (215). Histologically, these lesions were similar to those found in humans, suggesting that autoimmunity may be an important mechanism. Furthermore, these studies suggest that $\mathrm{CD}^{+} \mathrm{T}$ cells play a major role in the production of these lesions (215). However, the link between these various observations and the pathogenesis of the lesions of chronic Chagas' disease continues to be studied experimentally and debated $(61,118,121,122,172,196,197,215,243,269,274)$.

\section{PATHOGENESIS OF NEUROLOGICAL MANIFESTATIONS}

The pathogenesis of the neurological manifestations associated with Chagas' disease is still incompletely understood (133). Both the peripheral (143) and central nervous systems undergo various degrees of destruction during acute disease. The autonomic nervous system is particularly vulnerable to injury during this phase. The destruction of intracardiac ganglia, as well as intrinsic myenteric neurons of the gastrointestinal tract, in experimental animals and humans has been described (133).

Light and electron micrographic studies of the autonomic nervous system in acute murine Chagas' disease clearly demonstrate that Schwann cells and other supporting cells of the autonomic ganglia undergo destruction. Koeberle (133) has suggested that the destruction of nerve cells during acute infection leads to neuropathies that are manifested later in the illness. Although clinically inapparent, the greatest loss of neurons occurs during acute infection; further neuronal loss proceeds slowly over a prolonged period and leads to clinical manifestations in some patients.

Many investigators have attempted to explain the extensive neuronal destruction with limited or absent parasitism. An early proposal held that the parasite elaborated a neurotoxin. The participation of immune mechanisms in neuronal destruction has received much attention $(120,226)$. It has been reported that denervation precedes the appearance of anti-nerve cell immune response and that parasite antigens can be adsorbed onto nerve cells, making the cells targets for the anti-T. cruzi immune response (214). Several monoclonal antibodies have been reported to show cross-reactivity between parasite and neural tissue, and so it has been sug- gested that demyelination of the peripheral nervous system is due in part to immune mechanisms. The possible autoimmune nature of the neuropathological lesions continues to be investigated (226). For example, there have been reports of antibodies that cross-react with epitopes of $T$. cruzi and mammalian neurological tissue, but the relationship of these observations to human neuropathological changes has not been established $(198,241,274,283)$.

Further studies of the pathogenesis of the neurological consequences of infection have revealed neurochemical alterations. For example, the number of nicotinic acetylcholine receptors was increased and the acetyl cholinesterase levels were decreased in tissues obtained from acutely infected animals $(31,251)$. These data are consistent with the phenomenon of denervation hypersensitivity noted in human Chagas' disease.

\section{CHRONIC GASTROINTESTINAL DISEASE}

Chronic Chagas' disease is associated with a decrease in Auerbach's and Meissner's plexuses. Additionally, there are preganglionic lesions and a reduction in the number of dorsal cells of the motor nucleus of the vagus. The preganglionic losses are thought to be due to retrograde destruction resulting from loss of neurons in the gut plexuses. Although it is believed that most of the damage to the nervous system occurs during acute infection, further neuronal loss occurs slowly over an extended period (133). The development of chronic gastrointestinal disease may take several decades, and the determinants of progression are unknown. Koeberle (133) has shown that colonic disease associated with Chagas' disease is associated with a $50 \%$ loss of neurons and that esophageal disease is associated with an $85 \%$ loss. In autopsy studies by Chapadeiro et al. (44), there was a $35 \%$ incidence of megacolon or megaesophagus, and Barbara et al. (19) reported a 5.8\% incidence of cardiomyopathy and a $1 \%$ incidence of megacolon or megaesophagus in 15,000 autopsies in an area of endemicity.

\section{Colon}

The colon is frequently involved in patients with chronic Chagas' disease (Fig. 5). Although the entire colon may be enlarged, usually only sigmoid dilation is found $(71,255)$. Constipation is a common presenting complaint (133). Some patients experience little or no discomfort and seek medical attention only because of complications such as sigmoid volvulus, fecaloma with stercol ulceration, ulcer perforation associated with peritonitis, or, rarely, primary perforation without a previous ulcer (133). Symptomatic patients may have motility disorders that antedate the radiological diagnosis of megacolon $(70,71)$. The colon increases in length before it increases in diameter. Thickening of the circular muscle layer (154) occurs early in the disease. In chagasic patients with megacolon (70), there is a reduction in the number of ganglia throughout the colon (133).

In patients with sigmoid megacolon, manometric studies reveal complex waves, simultaneous contractions, and contraction waves of high amplitude and long duration (102). Orderly peristaltic waves are not ordinarily found during sigmoid manometric studies. Acetylcholinergic agents such as mecholyl have been successfully used to determine ganglion cell loss, since denervated gut is hypersensitive and contracts more vigorously than normal. Chagasic patients with $(153,277)$ and without $(239)$ megacolon are hypersen- 

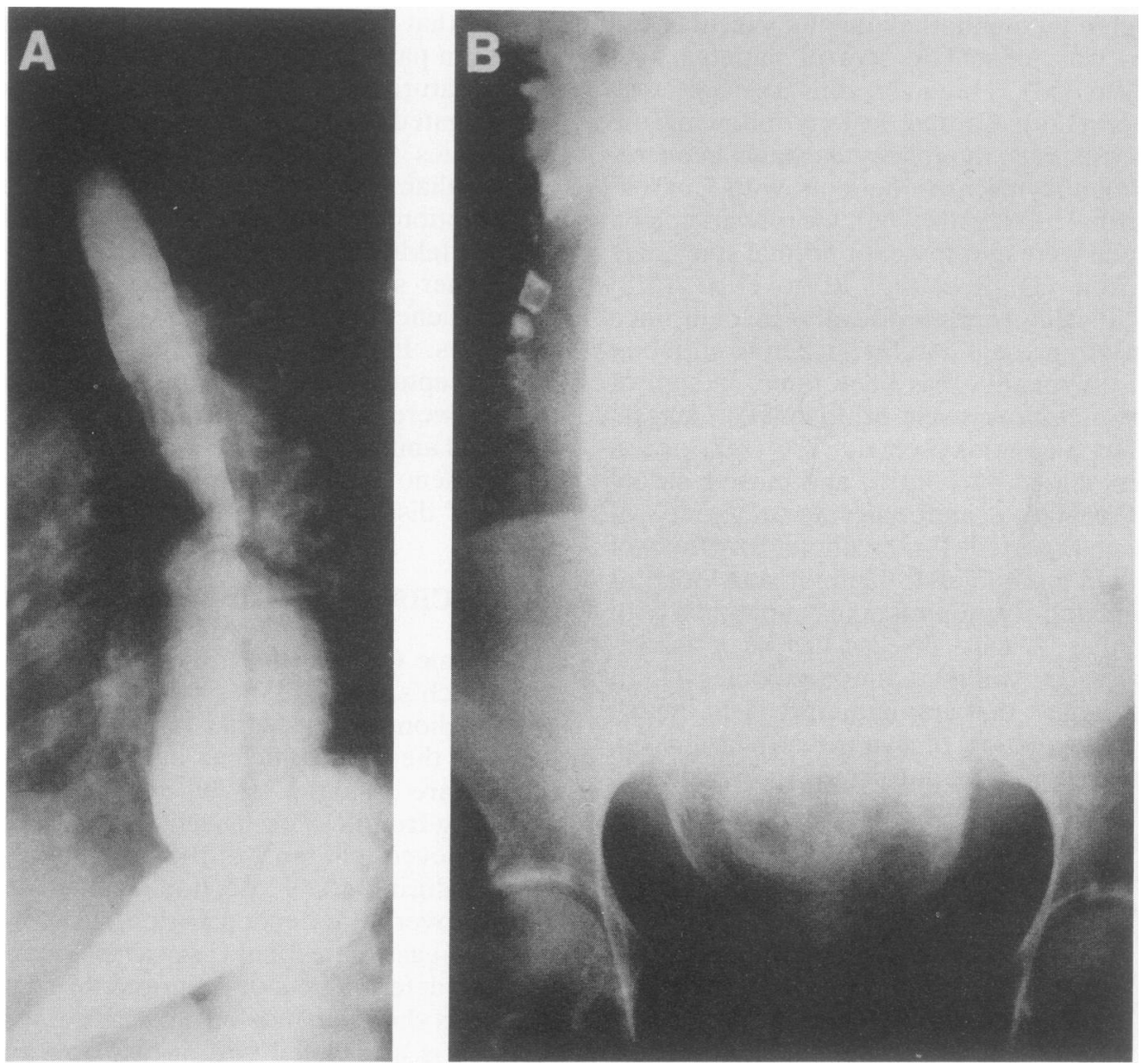

FIG. 5. Megaesophagus (A) and megacolon (B) in a Brazilian woman. Reprinted from reference 255 with permission of S. Karger.

sitive to mecholyl but less so than patients with megaesophagus, suggesting denervation hypersensitivity.

Colonic denervation has been used to study the effects of a number of pharmacological agents and hormones. For example, gastrin and pentagastrin stimulate colonic and rectal motility in normal individuals $(52,240)$. Pentagastrin has no effect on chagasic patients with megacolon but stimulates motility in controls and chagasic patients without megacolon (155), indicating that the effect is partly dependent on the presence of an intact myenteric plexus. Cholecystokinin and infusion of intraduodenal amino acids stimulate motility in normal patients (67). This effect is inhibited by naloxone but not atropine (209). These infusions have no effect in chagasic patients with megacolon, suggesting that the colonic myenteric plexus includes enkephalin-containing neurons (145). Studies of rectal biopsy samples from patients with Chagas' disease have shown reduced levels of substance $P$, vasoactive intestinal polypeptide, somatostatin, and enterglucagon (141). These neurohumoral peptides do not show reduced levels in patients with chronic autonomic neuropathy (141), which is an abnormality of preganglionic extrinsic nerves. However, the elaboration of these products is neuronally mediated, and the decreases that have been reported in patients with Chagas' disease are probably due to a reduction in ganglion cells. These changes and the diminished level of enteroglucagon in affected patients suggest that observed abnormalities in colonic function are due to both denervation hypersensitivity and an imbalance of gut hormones.

\section{Esophagus}

The myenteric plexus constitutes $5 \%$ of the total esophageal mass (133), and neuron density varies along the length of the esophagus, increasing from the level of the cricoid cartilage to the midesophagus and maintaining this density to the cardia. The aging process is associated with a decrease in the number of ganglia. This may partially explain the tertiary contractions, delayed emptying, moderate dilation, and altered peristalsis associated with aging (242). Koeberle (133) reported that ganglion counts from 40 autopsies of chagasic patients with grossly normal esophaguses were lower than counts in healthy controls. The data from motility studies on patients with Chagas' disease have varied $(94,142,162,163$, 276).

Patients with megaesophagus may have less than $95 \%$ of the normal number of ganglia (133). The loss of neurons is uniform along the length of the esophagus, including the grossly normal abdominal portion of the esophagus. A megaesophagus can reach 26 times its normal weight and hold up to 2 liters of fluid (130). Histologically, there is epithelial thickening with cornification, leukocytic infiltration (occasionally deep into the muscularis mucosa and submucosa), and hypertrophy of the muscularis mucosa and muscularis propria $(131,132,201)$. The thickened mucosa may have erosions and esophagitis as a result of stagnation. There is a $10 \%$ incidence of squamous cell carcinoma of the esophagus (35), perhaps related to chronic inflammation in these patients. 
Megaesophagus may present with dysphagia, regurgitation, odynophagia, eructation, fullness, and cough $(34,211-$ 213). In chagasic patients with megaesophagus, there is an increased incidence of aspiration pneumonia and pulmonary tuberculosis compared with patients with only cardiomyopathy (35). In one study, $50 \%$ of patients with megaesophagus presented between ages 20 and 39 (212). Megaesophagus in a neonate born with congenital Chagas' disease has been reported (27).

Megaesophagus is accompanied by delayed emptying that is secondary to dysfunction of the lower esophageal sphincter and the body of the esophagus. This may result in retained material, causing dilation. Manometric studies of asymptomatic chagasic patients (200) have demonstrated that after initiation of a swallow, esophageal peristalsis occurs more than $50 \%$ of the time and synchronous waves occur more than $80 \%$ of the time. In symptomatic patients, esophageal peristalsis follows initiation of swallowing approximately $20 \%$ of the time and synchronous waves occur approximately $40 \%$ of the time. In patients with symptoms and esophageal dilation, the lower esophageal sphincter rarely relaxes with swallowing, whereas in those with symptoms and a nondilated esophagus, relaxation occurs following $37 \%$ of swallows. In asymptomatic patients, the sphincter relaxes following 75 to $85 \%$ of initiated swallows irrespective of the presence or absence of dilation. Pessoa (195) has shown that in $50 \%$ of asymptomatic chagasic patients, the lower esophageal sphincter fails to relax after swallowing (132). Collectively, these data suggest that esophageal body abnormalities can occur independently of the lower esophageal sphincter dysfunction. The presence of symptoms therefore appears to be associated with loss of peristalsis and failure of sphincter relaxation, leading to dilation. Studies of lower esophageal sphincter pressures in patients with Chagas' disease have demonstrated variable results $(57,60,107,162,190,191,276)$. This contrasts with the uniformly elevated lower esophageal sphincter pressures in patients with idiopathic achalasia.

In patients with Chagas' disease, gastrin levels in plasma are elevated (271) and the response of lower esophageal sphincter pressure to glucagon is unchanged or diminished (212). Both noncholinergic inhibitory and cholinergic excitatory nerve responses are impaired (58), and the lower esophageal sphincter is hypersensitive to gastrin. Patients with idiopathic achalasia have normal gastrin levels (46) and a decreased sphincter response to glucagon (113). It has been reported that there is an impaired response of noncholinergic inhibitory nerves (69) and a normal response of cholinergic excitatory nerves (47) and that the lower esophageal sphincter is hypersensitive to gastrin (52).

The treatment of megaesophagus consists of either surgery or dilatation of the lower esophageal sphincter. Comparison of bouginage with pneumatic dilatation (204) demonstrated pneumatic dilatation to be superior. If surgical treatment fails, pneumatic dilatation is recommended. Nifedipine (59) and isosorbide dinitrite (60) reduced lower esophageal sphincter pressure in patients with Chagas' disease and may be useful as medical therapy.

\section{Stomach}

Symptomatic gastric involvement in Chagas' disease is rare (55), despite a significant reduction in the number of ganglion cells. There is decreased gastric secretion (190) and reduced acid and pepsin output in response to pentagastrin; this may be corrected by bethanechol (189). Approximately one-third of patients with gastrointestinal organomegaly and one-third of patients with cardiomyopathy are achlorhydric (86). Intragastric pressures in response to saline infusion, which is a measure of gastric accommodation, are higher in patients with Chagas' disease than in controls (43). This lack of accommodation may explain the rapid emptying in patients with Chagas' disease, which is similar to that seen after surgical vagotomy and underscores the fact that the vagal pathway including the myenteric plexus is needed for reservoir function.

There is an increased incidence of gastric ulcer, as well as chronic superficial gastritis, in patients with Chagas' disease (272). This may suggest duodenogastric reflux. However, there are no reported differences between duodenogastric reflux in patients with Chagas' disease and in controls, and the increased incidence of gastric ulcer and gastritis in the former group thus remains an enigma.

\section{Small Intestine}

Isolated small-intestinal dilation is uncommon (4). The loss of ganglion cells in the duodenum of patients with chronic Chagas' disease is common. Small-intestine transit times are most often normal in patients with Chagas' disease, but they are increased in $32 \%$ of patients and decreased in $4 \%$ (184). Small-intestine motility in chagasic patients with and without organomegaly and in normal controls was studied. The migrating motor complex was detected with equal frequency in both groups, and the contraction frequency during an activity front was also the same. Activity front propagations were slower, their durations in the jejunum (but not the duodenum) were longer, and their calculated lengths were shorter in patients with chronic Chagas' disease. This indicates that myenteric neurons and hormonal factors are involved in normal migration of the migratory complex (255).

Studies of intestinal absorption are limited. Chagasic patients appear to have increased absorption of glucose, galactose, and xylose. These disturbances are probably due to rapid gastric emptying rather than to abnormalities in small-intestine absorption, because glucose tolerance is normal after parenteral loading. In addition, fecal fat excretion appears to be normal in chagasic patients $(37,38,156,157)$.

\section{Gallbladder}

Chagas' disease is associated with a $0.6 \%$ incidence of megagallbladder (219). There is an increase in cholelithiasis among patients with megaesophagus and megacolon (278). Gallbladder contractility in response to cholecystokinin in chagasic patients may be increased, normal, or decreased, a situation similar to that in nonchagasic patients after vagotomy $(50,99)$. Sphincter of Oddi manometry in patients with megaesophagus revealed elevated basal pressures and amplitude of contractions. After cholecystokinin infusion, there was an increased pressure gradient between the common bile duct and duodenum and decreased basal sphincter pressures. "Mega" syndromes involving nongastrointestinal organs, such as megaureter, have also been reported (133).

\section{DIAGNOSIS}

The diagnosis of acute $T$. cruzi infection is generally made by detection of parasites. Active trypomastigotes frequently can be seen by microscopic examination of fresh anticoagulated blood or of the buffy coat. Parasites can also be seen on 
Giemsa-stained thin and thick blood smears. When organisms cannot be detected by these approaches, one may inoculate blood specimens or the buffy coat intraperitoneally into mice and examine samples of their blood, obtained by tail snips, microscopically every 2 to 3 days thereafter. Also, blood and buffy coat specimens should be cultured in liquid medium, and parasites may be observed microscopically in such cultures after several weeks. When acute Chagas' disease is suspected in an immunocompromised patient and these methods fail to demonstrate the presence of $T$. cruzi, additional tissue specimens should be examined. These patients can pose a difficult diagnostic problem because they may present with fulminant clinical disease and low parasitemias that cannot be readily detected. Surprisingly, parasites can sometimes be seen in atypical sites, such as pericardial fluid, bone marrow, brain, skin, and lymph nodes, and thus these tissues also should be investigated when indicated $(91,97,140,244)$.

A last resort for the detection of acute $T$. cruzi is xenodiagnosis, a method in which several dozen laboratory-reared reduviid bugs are fed blood from the person suspected of having acute Chagas' disease. Then 30 to $\mathbf{4 0}$ days after the blood meal, the bugs' intestinal contents are examined microscopically for parasites. Although this procedure is perhaps the most sensitive approach for diagnosing acute $T$. cruzi infection, it is usually positive for only $50 \%$ of patients with chronic Chagas' disease.

The diagnosis of chronic Chagas' disease is generally based on detecting specific antibodies that bind to $T$. cruzi antigens. A number of highly sensitive serological assays are used in Latin America for detecting anti-T. cruzi antibodies, such as the complement fixation and indirect immunofluorescence tests and the enzyme-linked immunosorbent assay (ELISA) (36). These and other conventional serologic assays are used widely for clinical diagnosis and for screening donated blood, as well as in epidemiological studies. The occurrence of occasional false-positive reactions, however, has been a persistent problem with these assays. Since procedures for making a specific parasitological diagnosis (xenodiagnosis or blood culture) are insensitive and laborious and take several weeks to complete, a number of research laboratories have tried to develop tests that would have the sensitivity of the conventional assays and be highly specific yet easy to perform. An assay based on the immunoprecipitation of radiolabeled protein antigens followed by electrophoresis was found to be highly specific as well as sensitive when used in a clinically and geographically diverse group of $T$. cruzi-infected persons (128). Although this complex test has not been adapted for use on large numbers of serum samples, it is presently available as a confirmatory assay in one of our laboratories (that of L.V.K.).

Taking another approach, several laboratories in recent years have been performing DNA sequence determinations on $T$. cruzi genes that code for antigenic proteins in an effort to produce recombinant proteins and synthetic peptides that could be used as targets in assays for anti-T. cruzi antibodies. A sizable number of DNA sequences encoding proteins that are specifically recognized by serum from $T$. cruziinfected patients have been reported, and in many cases, these proteins have been evaluated in diagnostic assays (32, 135; reviewed in references 84, 85, and 160). An example of such work is reported in a paper by Cotrim et al. (56), who used human chagasic serum to isolate a fragment of a $T$. cruzi gene that encodes a recombinant protein, designated H49. In blots of phage plaques, H49 reacted with serum samples from 115 chagasic patients but not with any of 70 comparison samples. These results, when taken together with those reported by other investigators who used different recombinant antigens, suggest that the general approach of using recombinant proteins as targets in immunoassays for $T$. cruzi infection may resolve the problem of false-positive reactions that has persisted in the conventional assays, while still maintaining high sensitivity.

The detection of chronic $T$. cruzi infection by testing for parasite antigens in blood or urine has been under investigation for several years. In a recent report describing work in this area, Quaissi et al. (187) described the characterization of an $85-\mathrm{kDa}$ secretory antigen of $T$. cruzi found on the surfaces of the mammalian stages of the parasite. Using a monoclonal antibody that binds to this antigen, they developed an ELISA to detect the antigen in serum samples from patients with Chagas' disease and controls. Unfortunately, although mean levels of reactivity were much higher in the serum samples from $T$. cruzi-infected persons than in samples from controls, the reactivities of 11 of the 80 Chagas' disease samples tested were lower than the highest levels of the comparison samples. These overlapping findings are similar to those reported by Araujo et al. (14) more than a decade ago and raise serious doubt about the usefulness of this approach. The utility of parasite antigen detection in urine has also been studied. It has been demonstrated that $T$. cruzi antigens can readily be detected in urine from patients with acute Chagas' disease (87), but more recent work suggests that this method will not be useful for diagnosis of patients with chronic $T$. cruzi infection (116).

The polymerase chain reaction (PCR) can be used as a highly sensitive method for detecting microbial DNA, and it would appear to be particularly suited for the task of detecting the small numbers of parasites circulating in patients chronically infected with $T$. cruzi (73). Sturm et al. (245) used a 120-bp region of the T. cruzi kinetoplast minicircle as a target for PCR amplification. When purified parasite DNA was amplified, they were able to detect as little as $0.1 \%$ of the genome of a single parasite, even in the presence of a several billion-fold excess of human DNA. Moreover, they detected as few as 10 parasites in $100 \mu l$ of blood from an infected mouse. A more recent report from the same laboratory (16) described technical refinements and presented the positive results obtained with blood from five patients known to be infected with $T$. cruzi. In a second approach to using PCR to detect $T$. cruzi, Moser et al. (173) amplified a 188-bp repetitive nuclear DNA sequence and were able to detect as little as $0.05 \%$ of the DNA of a single parasite. Moreover, eight parasites in $100 \mu l$ of mouse blood were easily detected, and the presence of $T$. cruzi in the intestinal contents and urine of infected reduviid bugs was also demonstrated.

A decision regarding the usefulness of these two PCRbased assays for routine detection of $T$. cruzi awaits their evaluation in epidemiologic studies and in blood banks, where both sensitivity and specificity are assessed by testing sizable numbers of infected and uninfected persons. $T$. cruzi parasitemias may in fact be intermittent in chronically infected individuals, and this may limit the sensitivity of the assays. Furthermore, PCR-based assays require processing of blood samples and testing procedures that are considerably more complicated than those required to perform serological assays. This factor, in addition to the potential problem of false-positive reactions resulting from contamination of samples with amplification products generated in previous test runs, may be a major obstacle to the widespread use of PCR for the diagnosis of $T$. cruzi infection, 
especially in the developing countries in which Chagas' disease is endemic. The high sensitivity of the two PCRbased assays described above suggests that they may be useful for the diagnosis of acute and congenital $T$. cruzi infections $(18,26)$, but these applications have not been studied. Recently, Reyes et al. (210) have reported another assay to aid in the diagnosis of congenital Chagas' disease, based on fetal IgG.

\section{TREATMENT}

The treatment of $T$. cruzi infection is problematic, since the protozoan is not susceptible to most of the drugs tested for activity, including those effective against the African trypanosomes and other protozoans (150). Nifurtimox (Lampit; Bayer 2502) and benznidazole (Radamil; Roche 7-1051), the two drugs available for treating $T$. cruzi, effectively reduce the severity of acute Chagas' disease but have no role in the therapy of chronic infections. Both must be taken for extended periods and may cause severe side effects. In addition, many patients given full courses of treatment are not cured parasitologically. Additional concern has been raised by studies reported by Teixeira et al. $(264,265)$, in which $42 \%$ of rabbits receiving benznidazole and $33 \%$ of rabbits receiving nifurtimox developed widely invasive lymphomas, whereas none of the control animals developed tumors. These findings should be a source of concern, but they should be viewed from the perspective that both drugs have been used widely for several decades in Latin America and reports of an increased frequency of lymphomas in treated patients have not appeared.

A study involving allopurinol treatment of patients with chronic Chagas' disease has been reported. Allopurinol, an inhibitor of hypoxanthine oxidase, is active against $T$. cruzi in mammalian cell cultures and in mice (17). It was as effective as benznidazole and nifurtimox in suppressing $T$. cruzi parasitemias, as measured by xenodiagnosis, and in causing conventional serological tests to become negative (88). The advantage of allopurinol would be its relative lack of side effects. However, the open, nonrandomized study structure used and the lack of clearly defined criteria for parasitological cure of $T$. cruzi infection make interpretation of the findings of this study difficult.

Efforts at identifying and developing new drugs for treating $T$. cruzi infections continue in a small number of laboratories. The anti-T. cruzi activity of several inhibitors of bacterial topoisomerases has been studied in vivo (95a). Marked inhibition of parasite proliferation and differentiation was caused by several drugs in this class, suggesting that $T$. cruzi has an enzyme similar to the topoisomerase II of bacteria, thus opening a new avenue in the search for an effective and nontoxic agent for the treatment of $T$. cruzi. Subsequent work by some of the authors of this latter study resulted in the molecular cloning of a protein in $T$. cruzi that has an $80 \%$ amino acid identity with topoisomerase II of Trypanosoma brucei (82).

\section{TRANSFUSION-ASSOCIATED TRANSMISSION OF T. CRUZI INFECTION}

Transmission of $T$. cruzi by transfusion of blood donated by asymptomatic persons who harbor the parasite is a major public health problem in many countries where the disease is endemic (234). The problem has been exacerbated in recent years because of political turmoil and economic hardships that have resulted in large-scale migrations of persons at risk. The epidemiology of chronic $T$. cruzi infection in the United States has changed markedly in the past 15 years because of this phenomenon. During this period, several million people have entered the country from Central and South America, regions with a high prevalence of $T$. cruzi infection (234). In a study done in Washington, D.C., in $1985,4.9 \%$ of Nicaraguan and Salvadoran immigrants were infected with $T$. cruzi, suggesting that there may be more than 50,000 infected people living in the United States (127). The presence of these infected individuals raises a number of important public health issues, including the risk of transmission of the parasite by blood transfusion (125). Evidence of this risk was provided in recent studies carried out in a Los Angeles blood bank, in which approximately 1 in 1,000 prospective donors was found to be infected $(13,117)$.

Furthermore, the reality of the risk of transfusion-associated transmission of $T$. cruzi in countries in which the parasite is not endemic was highlighted by the occurrence of three cases of acute Chagas' disease in immunosuppressed patients who received blood from donors who were unaware of being infected with $T$. cruzi $(91,97,177)$. The courses of the illnesses in these patients were particularly fulminant because of the immunosuppression, and this probably contributed to the detection of $T$. cruzi. This suggests that other cases of transfusion-associated transmission of $T$. cruzi are occurring in the United States but are not recognized because the courses of illness are more benign.

The question of how to reduce the risk of transmission of $T$. cruzi in U.S. blood banks is complex. Widespread serological screening of donated units would undoubtedly result in large numbers of false-positive reactions, since the overall prevalence of $T$. cruzi infection is low. Moreover, there is no commercially available test approved for use in the United States that has acceptable levels of sensitivity and specificity. Thus, the most prudent course at this time would be not to accept blood donations from persons who have lived under conditions in which transmission could have occurred in countries in which the parasite is endemic. Such a policy of donor deferral would have a negligible effect on the blood supply in most areas and would virtually eliminate the risk of transfusion-associated transmission of $T$. cruzi.

\section{IMMUNOSUPPRESSION AND TRANSPLANTATION}

For many years, it has been known that immunosuppression of experimental animals (8) and patients who chronically carry $T$. cruzi can lead to recrudescence of the disease. The incidence of reactivation of infection in immunosuppressed persons is not known, and articles describing both its absence (20) and its occurrence $(134,137,161,217,244)$ have been published. In view of the chance of acute reactivation of $T$. cruzi, patients who are at risk of being infected and for whom immunosuppressive treatment is being planned, as either primary or posttransplantation therapy, should undergo serological testing and, if positive, should be monitored closely while immunosuppressed for evidence of reactivation. Several recent reports of reactivation of $T$. cruzi infection in human immunodeficiency virus-infected patients have appeared $(63,80,93,220)$. Interestingly, all of these patients developed cerebral lesions, which are rarely seen in immunocompetent patients with chronic $T$. cruzi infections.

Finally, more than a dozen patients with end-stage chagasic heart disease have undergone cardiac transplantation in Brazil (244), and the procedure has been done in a handful of chagasic patients in the United States as well (140). Not 
surprisingly, given the intensity of postoperative immunosuppression needed after heart transplantation, reactivation of $T$. cruzi infection occurred in the majority of these patients, often with severe consequences. Since the number of hearts available for transplantation is only a small percentage of the number of potential recipients, $T$. cruzi infection should be considered a contraindication for heart transplantation because of the likelihood of serious posttransplant complications related to reactivation of the parasitosis.

\section{CONCLUSION}

It has now been almost a century since Chagas' disease was first described. Despite the advances made on various aspects of this disease, there is still a lack of reliable therapeutic or prophylactic agents.

\section{ACKNOWLEDGMENTS}

The work described in this review was supported in part by grants AI-12770, AI-26338, AI-29747, and AI-24711 from the National Institutes of Health. L.V.K. is supported by an Established Investigatorship from the American Heart Association.

\section{REFERENCES}

1. Acosta, A. M., and C. A. Santos-Buch. 1985. Autoimmune myocarditis induced by Trypanosoma cruzi. Circulation 71: 1255-1261.

2. Acquatella, H., F. Catalioti, J. R. Gomez-Mancebo, V. Davalos, and $L$. Villalobos. 1987. Long-term control of Chagas' disease in Venezuela: effects on serologic findings, electrocardiographic abnormalities, and clinical outcome. Circulation 76: 556-562.

3. Acquatella, H., and N. B. Schiller. 1988. Echocardiographic recognition of Chagas' disease and endomyocardial fibrosis. J. Am. Soc. Echocardiography 1:60-68.

4. Alcantara, F., and R. Costa. 1966. Jejunopatia chagasica. Rev. Bras. Med. 23:316-317.

5. Amorin, D. S. 1979. Chagas' disease. Prog. Cardiol. 8:235-279.

6. Amorim, D. S., and E. G. Olsen. 1982. Assessment of heart neurons in dilated (congestive) cardiomyopathy. Br. Heart $\mathrm{J}$. 47:11-18.

7. Andrade, S. G., and J. A. Grimaud. 1986. Chronic murine myocarditis due to Trypanosoma cruzi: an ultrastructural study and immunochemical characterization of cardiac interstitial matrix. Mem. Inst. Oswaldo Cruz Rio J. 81:29-41.

8. Andrade, Z. A., S. Andrade, and M. Sadigursky. 1987. Enhancement of chronic Trypanosoma cruzi myocarditis in dogs treated with low doses of cyclophosphamide. Am. J. Pathol. 127:467-473.

9. Andrade, Z. A., S. G. Andrade, G. B. Oliveira, and D. R. Alonso. 1978. Histopathology of the conducting tissue of the heart in Chagas' myocarditis. Am. Heart J. 95:316-324.

10. Andrade, Z. A., S. G. Andrade, M. Sadigursky, and J. H. Maguire. 1981. Experimental Chagas' disease in dogs. A pathologic and ECG study of the infection. Arch. Pathol. Lab. Med. 105:460-464.

11. Andrews, N. W., C. K. Abrams, S. L. Slatin, and G. A. Griffiths. 1990. A T. cruzi-secreted protein immunologically related to the complement component C9: evidence for membrane pore-forming activity at low pH. Cell 61:1277-1287.

12. Andrews, N. W., E. S. Robbins, V. Ley, K. S. Hong, and V. Nussenzweig. 1988. Developmentally regulated, phospholipase C-mediated release of the major surface glycoprotein of amastigotes of Trypanosoma cruzi. J. Exp. Med. 167:300-314.

13. Appleman, M. D., I. A. Shulman, S. Saxena, and L. V. Kirchhoff. Use of a questionnaire to identify potential donors at risk for infection with Trypanosoma cruzi. Transfusion, in press.

14. Araujo, F. G., E. Chiari, and J. C. P. Dias. 1981. Demonstra- tion of Trypanosoma cruzi antigen in serum from patients with Chagas' disease. Lancet ii:246-249.

15. Arreaza, N., J. J. Puigbo, H. Acquatella, R. Valecillos, I. Mendoza, J. F. Perez, E. Hirschhaut, and I. Combellas. 1983. Radionucleotide evaluation of left ventricular function in chronic Chagas' cardiomyopathy. J. Nucl. Med. 24:563-567.

16. Avila, H. A., D. S. Sigman, L. M. Cohen, R. C. Millikan, and L. Simpson. 1991. Polymerase chain reaction amplification of Trypanosoma cruzi kinetoplast minicircle DNA isolated from whole blood lysates: diagnosis of chronic Chagas' disease. Mol. Biochem. Parasitol. 48:211-222.

17. Avila, J. L., and A. Avila. 1981. Trypanosoma cruzi: allopurinol in the treatment of mice with experimental acute Chagas disease. Exp. Parasitol. 51:204-208.

18. Azogue, E., C. La Fuente, and C. Dorras. 1985. Congenital Chagas' disease in Bolivia: epidemiological aspects and pathological findings. Trans. R. Soc. Trop. Med. Hyg. 79:176-180.

19. Barbara, A., J. Pittella, and W. Tafuri. 1970. Incidencia da cadiopatia Chagasica em 15,000 necropsias consecutivas e su a associacao com os "Megas." Reuta Soc. Bras. Med. Trop. 4:219-223.

20. Barousse, A. P., J. A. Costa, M. Esposto, H. Laplume, and E. L. Segura. 1980. Enfermedad de Chagas e inmunosupresión. Medicina (Buenos Aires) 40(Suppl. 1):17-26.

21. Barr, S., S. P. Schmidt, C. C. Brown, and T. R. Klei. 1991. Pathologic features of dogs inoculated with North American Trypanosoma cruzi isolates. Am. J. Vet. Res. 52:2033-2039.

22. Beard, C. B., D. G. Young, J. F. Butler, and D. A. Evans. 1988. First isolation of Trypanosoma cruzi from a wild-caught Triatoma sanguisuga (LeConte) (Hemiptera: Triatominae) in Florida, U.S.A. J. Parasitol. 74:343-344.

23. Ben Younes-Chennoufi, A., G. Said, H. Eisen, A. Durand, and M. Hontebeyrie-Joskowicz. 1988. Cellular immunity to Trypanosoma cruzi is mediated by helper T cells $\mathrm{CD} 4^{+}$. Trans. $\mathrm{R}$. Soc. Trop. Med. Hyg. 82:84-89.

24. Bestetti, R. B., and J. S. M. Oliveira. 1989. A hitherto neglected cause of myocardial infarction associated with normal coronary arteries: chronic Chagas' disease. Am. J. Cardiol. 63:766.

25. Bevilacqua, M. P., J. S. Pober, G. R. Majeau, R. S. Cotran, and M. A. Giambrone. 1985. Interleukin-1 acts on cultured human vascular endothelium to increase adhesion of polymorphonuclear leukocytes, monocytes, and related leukocyte cell lines. J. Clin. Invest. 76:2003-2011.

26. Bittencourt, A. L. 1976. Congenital Chagas' disease. Am. J. Dis. Child. 130:97-103.

27. Bittencourt, A. L., G. O. Vieira, H. C. Tavares, E. Mota, and J. Maguire. 1984. Esophageal involvement in congenital Chagas' disease. Am. J. Trop. Med. Hyg. 33:30-33.

28. Bonaldo, M. C., T. Souto-Podrom, W. de Souza, and S. Goldenberg. 1988. Cell substrate adhesion during Trypanosoma cruzi differentiation. J. Cell Biol. 106:1349-1358.

29. Brener, Z. 1973. Biology of Trypanosoma cruzi. Annu. Rev. Microbiol. 27:347-382.

30. Brener, Z. 1984. Laboratory-acquired Chagas' disease: an endemic disease among parasitologists, p. 3-9. In C. More (ed.), Genes and antigens of parasites, 2nd ed. Fundacao Oswaldo Cruz, Rio de Janeiro, Brazil.

31. Brennessel, D. J., M. Wittner, V. Braunstein, and H. B. Tanowitz. 1985. Acetylcholinesterase levels in skeletal muscle of mice infected with Trypanosoma cruzi. Am. J. Trop. Med. Hyg. 34:460-464.

32. Burns, J. M., Jr., W. G. Shreffler, D. E. Rosman, P. R. Sleath, C. J. March, and S. G. Reed. 1992. Identification and synthesis of a major conserved antigenic epitope of Trypanosoma cruzi. Proc. Natl. Acad. Sci. USA 89:1239-1243.

33. Caeiro, T., L. M. Amuchastegui, E. Moreyra, and D. G. Gibson. 1985. Abnormal left ventricular diastolic function in chronic Chagas' disease: an echocardiographic study. Int. J. Cardiol. 9:417-424.

34. Camara, E., J. Lima, G. B. Oliviera, and A. Machado. 1983. Pulmonary findings in patients with chagasic megaesophagus. Chest 83:87-91.

35. Camara-Lopes, L. H. 1962. The endemic South American 
megaesophagus. Surgical treatment of megaesophagus, p. 79 85. In F. Ingelfinger and G. Siffert (ed.), 2nd World Congress of Gastroenterology, vol. I. S. Karger, Basel.

36. Camargo, M. E. 1988. American trypanosomiasis (Chagas' disease), p. 744-753. In A. Balows, W. J. Hausler, Jr., and E. H. Lennette (ed.), Laboratory diagnosis of infectious diseases: principles and practice. Springer-Verlag, New York.

37. Campos, J., and J. Canada. 1962. Curvas glicemicas anormais observadas em pacientels com a forma cronica da molestia de Chagas. Hospital (Rio de Janiero) 62:275-278.

38. Campos, J., and W. Tafuri. 1973. Chagas' enteropathy. Gut 14:910-919.

39. Campos de Carvalho, A. C., H. B. Tanowitz, R. Dermietzel, E. L. Hertzberg, M. Wittner, and D. C. Spray. 1992. Gap junction distribution is altered between cardiac myocytes infected with Trypanosoma cruzi. Circ. Res. 70:733-742.

40. Carrasco, H. A., J. S. Barboza, G. Inglessis, and A. Fuenmayor. 1982. Left ventricular cineangiography in Chagas' disease: detection of early myocardial damage. Am. Heart J. 104:595602.

41. Casado, J., D. F. Davila, J. H. Donis, A. Torres, A. Payares, R. Colmenares, and C. F. Gottberg. 1990. Electrocardiographic abnormalities and left ventricular systolic function in Chagas' heart disease. Int. J. Cardiol. 27:55-62.

42. Cazzulo, J. J., R. Couso, A. Raimondi, C. Wernstedt, and U. Hellman. 1989. Further characterization and partial amino acid sequence of a cysteine proteinase from Trypanosoma cruzi. Mol. Biochem. Parasitol. 33:33-41.

43. Cerneviva, R., J. Modena, and P. Castelfranchi. 1971. Doenca de Chagas e ulcera gastrica. Arq. Gastroenterol. (Sao Paulo) 8:85-88.

44. Chapadeiro, E., E. Lopes, P. Mesquita, and F. E. Pereira. 1964. Incidencia de "Megas" associados a cardiopatia Chagasica. Rev. Inst. Med. Trop. Sao Paulo 6:287-291.

45. Chuster, M. 1985. Implante de Marcapasso nas Bradiarritmias Chagasicas, p. 289-297. In J. R. Cancado and M. Chuster (ed.), Cardiopatia chagasica. Fundacao Carlos Chagas, Belo Horizonte, Brazil.

46. Cohen, S., R. Fisher, and A. Tuch. 1972. The site of denervation in achalasia. Gut 13:556-558.

47. Cohen, S., W. Lipshultz, and W. Hughes. 1971. Role of gastric supersensitivity in the pathogenesis of lower esophageal hypertension in achalasia. J. Clin. Invest. 50:1241-1247.

48. Combellas, I., J. J. Puigbo, H. Acquatella, F. Tortoledo, and J. R. Gomez. 1985. Echocardiographic features of impaired left ventricular diastolic function in Chagas' heart disease. Br. Heart J. 52:298-309.

49. Connelly, M. C., and F. Kierszenbaum. 1984. Modulation of macrophage interaction with Trypanosoma cruzi by phospholipase A2-sensitive components of the parasite membrane. Biochem. Biophys. Res. Commun. 121:931-939.

50. Conte, V. 1981. Aspectos anatomo-funcionais da vesicula biliar em pacientes com megaesofago chagasico. Resta Hosp. Clin. Fac. Med. Unis. Sao Paulo 36:60-77.

51. Contreras, V. T., J. M. Salles, N. Thomas, C. M. Morel, and S. Goldenberg. 1985. In vitro differentiation of Trypanosoma cruzi under chemically defined conditions. Mol. Biochem. Parasitol. 16:315-327.

52. Cornell, A., and C. Loga. 1967. The role of gastrin in the ileocolic reflux. Am. J. Dig. Dis. 12:277-284.

53. Cornette, J., A. Capron, and M. A. Ouaissi. 1988. Trypanosoma cruzi: fibronectin promotes uptake of epimastigote culture forms by human neutrophils and monocytes. Int. Arch. Allergy Appl. Immunol. 86:139-146.

54. Cossio, P. M., C. Diez, A. Szarfman, E. Kreutzer, B. Candiolo, and R. Arana. 1974. Chagasic cardiopathy: demonstration of a serum gamma globulin factor which reacts with endocardium and vascular structures. Circulation 49:13-21.

55. Costa, R., and F. Alcantara. 1965. Gastropatia chagasica cronica. Rev. Bras. Med. 22:667-671.

56. Cotrim, P. C., G. S. Paranhos, R. A. Mortara, J. Wanderley, A. Rassi, M. E. Camargo, and J. F. da Silveira. 1990. Expression in Escherichia coli of a dominant immunogen of Trypanosoma cruzi recognized by human chagasic sera. J. Clin. Microbiol. 28:519-524.

57. Csendes, A., T. Strauszer, and P. Urabe. 1975. Alterations in normal esophageal motility in patients with Chagas' disease. Am. J. Dig. Dis. 20:437-442.

58. Dantas, R. 1988. Idiopathic achalasia and chagasic megaesophagus. J. Clin. Gastroenterol. 10:13-15.

59. Dantas, R., R. Godoy, R. Oliveira, M. G. Villanova, U. G. Meneghelli, and L. E. Troncon. 1986. Effect of nifedipine on the lower esophageal sphincter in chagasic patients. Braz. J. Med. Biol. Res. 19:205-209.

60. Dantas, R., J. Rezende, R. B. de Oliveira, and R. de Godoy. 1987. Effects of isosorbide dinitrate on the lower esophageal sphincter pressure in patients with Chagas' disease. Arq. Gastroenterol. 24:84-87.

61. Davila, D. F., R. O. Russell, and J. H. Donis. 1989. Cardiac parasympathetic abnormalities: cause or consequence of Chagas' heart disease. Parasitol. Today 5:327-329.

62. Dedman, J. R., B. R. Brukley, and A. R. Means. 1979. Regulation of microfilaments and microtubules by calcium and cyclic AMP. Adv. Cyclic Nucleotide Res. 11:131-174.

63. Del Castillo, M., G. Mendoza, J. Oviedo, R. P. Perez Bianco, A. E. Anselmo, and M. Silva. 1990. AIDS and Chagas' disease with central nervous system tumor-like lesion. Am. J. Med. 88:693-694.

64. De Morais, C. F., M. L. Higuchi, and S. Lage. 1989. Chagas' heart disease and myocardial infarct. Incidence and report of four necropsy cases. Ann. Trop. Med. Parasitol. 83:207-214.

65. de Paola, A. A. V., L. N. Horowitz, M. H. Miyamoto, R. Ribeiro, D. F. Ferreira, A. B. Terzian, C. Cirenza, N. Guiguer, and O. P. Portugal. 1990. Angiographic and electrophysiologic substrates of ventricular tachycardia in chronic Chagasic myocarditis. Am. J. Cardiol. 65:360-363.

66. Dias, J. C. P. 1987. Control of Chagas' disease in Brazil. Parasitol. Today 3:336-341.

67. Dinoso, V., M. Meshknop, S. Lorber, J. G. Gutierez, and W. Y. Chey. 1973. Motor response of the sigmoid colon and rectum to exogenous cholecystokinin and secretin. Gastroenterology 65: $438-444$.

68. Docampo, R., and O. P. Pignataro. 1991. The inositol phosphate/diacylglycerol signalling pathway in Trypanosoma cruzi. Biochem. J. 275:407-411.

69. Dodds, W., J. Dent, W. J. Hogan, G. K. Patel, J. Toouli, and R. C. Arndorfer. 1981. Paradoxical lower esophageal sphincter contraction induced by cholecystokinin-octapeptides in patients with achlasia. Gastroenterology 80:327-333.

70. Earlam, R. 1971. Ganglion cell changes in experimental stenosis of the gut. Gut 12:393-398.

71. Earlam, R. 1972. Gastrointestinal aspects of Chagas' disease. Dig. Dis. Sci. 17:559-571.

72. Eisenschlos, C. D., A. A. Paladini, L. Vedia, H. N. Torres, and M. M. Flawia. 1986. Evidence for existence of an $\mathbf{N}_{3}$-type regulatory protein in Trypanosoma cruzi membranes. Biochem. J. 237:913-917.

73. Eisenstein, B. I. 1990 . The polymerase chain reaction. A new method of using molecular genetics for medical diagnosis. $\mathbf{N}$. Engl. J. Med. 322:178-183.

74. Espinosa, R., H. A. Carrasco, F. Belandria, A. M. Fuenmayor, C. Molina, R. Gonzalez, and O. Martinez. 1985. Life expectancy analysis in patients with Chagas' disease: prognosis after one decade (1973-1983). Int. J. Cardiol. 8:45-56.

75. Factor, S. M., S. Cho, M. Wittner, and H. B. Tanowitz. 1984. Abnormalities of the coronary microcirculation in acute murine Chagas' disease. Am. J. Trop. Med. Hyg. 34:246-253.

76. Factor, S. M., T. Minase, S. Cho, R. Dominitz, and E. H. Sonnenblick. 1982. Microvascular spasm in the cardiomyopathic Syrian hamster: a preventable cause of focal myocardial necrosis. Circulation 66:342-354.

77. Factor, S. M., H. Tanowitz, M. Wittner, and M. C. Ventura. Interstitial connective tissue alterations in acute murine Chagas' disease. In N. R. Rose, K. L. Baughman, A. Herskowitz, and D. A. Neuman (ed.), Proceedings of the Second International Symposium on Immunologically Mediated Heart Dis- 
ease, in press. Springer-Verlag, Heidelberg, Germany.

78. Factor, S. M., M. Wittner, H. Tanowitz, M. C. Ventura, and M. Rojkind. 1990. Collagen matrix damage and trypanosome induced collagenolysis in murine Chagas' disease, abstr. 1155. Circulation 82(Suppl. III):291.

79. Ferrans, V. J., J. Milei, Y. Tomita, and R. A. Storino. 1988. Basement membrane thickening in cardiac myocytes and capillaries in chronic Chagas' disease. Am. J. Cardiol. 61:11371140 .

80. Ferreira, M. S., S. De Andrade Nishioka, A. Rocha, A. M. Silva, R. G. Ferreira, W. Olivier, and S. Toste, Jr. 1992. Acute fatal Trypanosoma cruzi meningoencephalitis in a human immunodeficiency virus-positive hemophiliac patient. Am. J. Trop. Med. Hyg. 45:723-727.

81. Figuêredo-Silva, J., J. Coutinho-Netto, R. B. Bestetti, and J. S. M. Oliveira. 1989. $\left({ }^{3} \mathrm{H}\right)$ acetylcholine release from rat atria in chronic chagasic cardiomyopathy. Braz. J. Med. Biol. Res. 22:737-740.

82. Fragoso, S. P., M. A. Carreira, and S. Goldenberg. 1991. Cloning and expression of Trypanosoma cruzi topoisomerase II gene. Mem. Inst. Oswaldo Cruz Rio J. 86:187. (Abstract.)

83. Frank, J. S., G. A. Langer, L. M. Nudd, and K. Seraydarian. 1977. The myocardial cell surface: its histochemistry and the effect of sialic acid and calcium removal on its structure and cellular ionic exchange. Circ. Res. 41:702-714.

84. Frasch, A. C. C., J. J. Cazzulo, L. Aslund, and U. Pettersson. 1991. Comparison of genes encoding Trypanosoma cruzi antigens. Parasitol. Today 7:148-151.

85. Frasch, A. C. C., and M. D. Reyes. 1990. Diagnosis of Chagas' disease using recombinant DNA technology. Parasitol. Today 6:137-139.

86. Fregtes, M. 1968. Gastric function studies in young patients with Chagas' disease. Rev. Esp. Enferm. Apar. Dig. 27:715724.

87. Freilij, H. L., R. S. Corral, A. M. Katzin, and S. Grinstein. 1987. Antigenuria in infants with acute congenital Chagas' disease. J. Clin. Microbiol. 25:133-137.

88. Gallerano, R. H., J. J. Marr, and R. R. Sosa. 1990. Therapeutic efficacy of allopurinol in patients with chronic Chagas' disease. Am. J. Trop. Med. Hyg. 43:159-166.

89. Gallo, L., J. M. Filho, B. C. Marciel, J. A. M. Neto, L. E. B. Martins, and E. C. L. Filho. 1987. Functional evaluation of sympathetic and parasympathetic system in Chagas' disease during dynamic exercise. Cardiovasc. Res. 21:922-927.

90. Garcia-Zapata, M. T. A., and P. D. Marsden. 1986. Chagas' disease. Clin. Trop. Med. Commun. Dis. 1:537-585.

91. Geiseler, P. J., J. I. Ito, B. R. Tegtmeier, P. R. Kerndt, and R. Krance. 1987. Fulminant Chagas' disease (CD) in bone marrow transplantation (BMT). Program Abstr. 27th Intersci. Conf. Antimicrob. Agents Chemother., abstr. 418.

92. Gimbrone, M. A. 1984. Interleukin 1 (IL-1) induces biosynthesis and cell surface expression of procoagulant activity in human vascular endothelial cells. J. Exp. Med. 160:618-623.

93. Gluckstein, D., J. Ruskin, F. Ciferri, W. D. Welch, and M. Grögl. 1988. Chagas' disease (CD): a new cause of cerebral mass in AIDS. Program Abstr. 28th Intersci. Conf. Antimicrob. Agents Chemother., abstr. 329.

94. Godoy, R., and N. Hadad. 1961. Tempo de transito esofeiges em portadores de molesta de Chagas. An. I Congr. Int. Doenca de Chagas. 2:591-601.

95. Golden, J. M., and R. L. Tarleton. 1991. Trypanosoma cruzi: cytokine effects on macrophage trypanocidal activity. Exp. Parasitol. 72:391-402.

95a.Gonzales-Perdomo, M., S. Lisboa de Castro, M. N. S. L. Meirelles, and S. Goldenberg. 1990. Trypanosoma cruzi proliferation and differentiation are blocked by topoisomerase II inhibitors. Antimicrob. Agents Chemother. 34:1707-1714.

96. Gonzales-Perdomo, M., P. Romero, and S. Goldenberg. 1988. Cyclic AMP and adenylate cyclase activators stimulate Trypanosoma cruzi differentiation. Exp. Parasitol. 66:205-212.

97. Grant, I. H., J. W. M. Gold, M. Wittner, H. B. Tanowitz, C. Nathan, K. Mayer, L. Reich, L. Wollner, L. Steinherz, F. Ghavimi, R. J. O'Reilly, and D. Armstrong. 1989. Transfusion- associated acute Chagas' disease acquired in the United States. Ann. Intern. Med. 111:849-851.

98. Greig, S., and F. Ashall. 1990. Electrophoretic detection of Trypanosoma cruzi peptidase. Mol. Biochem. Parasitol. 39:3137.

99. Guebrud, M., A. Bettarello, I. Cecconello, W. Pinotti, H. Mantelmacher, and H. Velasquez. 1983. Sphincter of Oddi pressure in chagasic patients with megaesophagus. Gastroenterology 85:584-588.

100. Guerra, H. A. C., E. Palacios-Pru, C. D. de Scorza, C. Molina, G. Inglessis, and R. V. Mendoza. 1987. Clinical histochemical and ultrastructural correlation in septal endomyocardial biopsies from chronic Chagasic patients: detection of early myocardial damage. Am. Heart J. 113:716-724.

101. Guzzetti, S., D. Iosa, M. Pecis, L. Bonura, M. Prosdocimi, and A. Malliani. 1991. Impaired heart rate variability in patients with Chagas' disease. Am. Heart J. 121:1727-1734.

102. Habr-Gana, A. 1967. Motilidade do colon sigmoido e do reto contribuicao para a fisiopatologia do megacolon chagasico. Rev. Hosp. Clin. Fac. Med. Sao Paulo 22:137-146.

103. Hagar, J. M., and S. H. Rahimtoola. 1991. Chagas' disease in the United States. N. Engl. J. Med. 325:763-768.

104. Hall, B. F., and K. A. Joiner. 1991. Strategies of obligate intracellular parasites for evading host defences. Parasitol. Today 7:A22-A27.

105. Hammermeister, K. E., T. Caeiro, E. Crespo, H. Palmero, and D. G. Gibson. 1984. Left ventricular wall motion in patients with Chagas' disease. Br. Heart J. 51:70-76.

106. Heath, S., S. Hieny, and A. Sher. 1990. A cyclic AMP inducible gene expressed during the development of infective stages of Trypanosoma cruzi. Mol. Biochem. Parasitol. 43:133-141.

107. Hectmann, P., and J. Espinoza. 1969. Oesophageal manometric studies in patients with chronic Chagas disease and megacolon. Gut 10:848-851.

108. Hernandez-Munain, C., M. A. Fernandez, A. Alcinar, and M. Fresno. 1991. Characterization of a glycosyl-phosphatidylinositol-anchored membrane protein from Trypanosoma cruzi. Infect. Immun. 59:1409-1416.

109. Hoff, R., R. S. Teixeira, J. S. Carvalho, and K. E. Mott. 1978 Trypanosoma cruzi in the cerebrospinal fluid during the acute stage of Chagas' disease. N. Engl. J. Med. 298:604-606.

110. Hoffilin, J. M., R. H. Sadler, and F. G. Araujo. 1987. Laboratory-acquired Chagas' disease. Trans. R. Soc. Trop. Med. Hyg. 81:437-440.

111. Hoppe, J., and K. G. Wagner. 1979. Cyclic AMP-dependent protein kinase I. A unique allosteric enzyme. Trends Biochem. Sci. 4:282-285.

112. Iosa, D., V. DeQuattro, D. Lee, U. Elkayam, and H. Palmero. 1989. Plasma norepinephrine in Chagas' cardioneuromyopathy. A marker of progressive dysautonomia. Am. Heart J. 117:882-887.

113. Jennewein, H. M., F. Waldeck, R. Siewert, F. W. Wiser, and R. Thimm. 1973. The interaction of glucagon and pentagastrin on the lower esophageal sphincter in man and dog. Gut 14:861864.

114. Joiner, K., S. Hieny, L. V. Kirchhofi, and A. Sher. 1985. gp72, the 72 kilodalton glycoprotein, is the membrane acceptor site for C3 on Trypanosoma cruzi epimastigotes. J. Exp. Med. 161:1196-1212.

115. Joiner, K., A. Sher, T. Gaither, and C. Hammer. 1986. Evasion of alternate complement pathway by Trypanosoma cruzi results from inefficient binding of factor B. Proc. Natl. Acad. Sci. USA 83:6593-6597.

116. Katzin, A. M., and E. S. Umezawa. 1991. Detection of urinary $T$. cruzi antigens in human chronic chagasic patients. Mem. Inst. Oswaldo Cruz Rio J. 86:69.

117. Kerndt, P. R., H. A. Waskin, L. V. Kirchhoff, F. Steurer, S. H. Waterman, J. M. Nelson, G. A. Gellert, and I. A. Shulman. 1991. Prevalence of antibody to Trypanosoma cruzi among blood donors in Los Angeles, California. Transfusion 31:814 818.

118. Kerner, N., P. Liegeard, M. J. Levin, and M. HontebeyrieJoskowicz. 1991. Trypanosoma cruzi: antibodies to a MAP-like 
protein in chronic Chagas' disease cross-react with mammalian cytoskeleton. Exp. Parasitol. 73:451-459.

119. Khoury, E. L., C. Diez, P. M. Cosio, and R. M. Arana. 1983. Heterophil nature of EVI antibody in Trypanosoma cruzi infection. Clin. Immunol. Immunopathol. 27:283-288.

120. Khoury, E. L., V. Ritacco, P. M. Cossio, R. P. Laguens, A. Szarfman, C. Diez, and R. M. Arana. 1979. Circulating antibodies to peripheral nerve in American trypanosomiasis (Chagas' disease). Clin. Exp. Immunol. 36:8-15.

121. Kierszenbaum, F. 1985. Auto-immunity in Chagas' disease: fact or fancy? Cause or consequence? Rev. Soc. Bras. Med. Trop. 18:129-132.

122. Kierszenbaum, F. 1986. Autoimmunity in Chagas' disease. J. Parasitol. 72:201-211.

123. Kierszenbaum, F. 1989. Chagas' disease, p. 173-195. In F. Y. Liew (ed.), Vaccination strategies of tropical diseases. CRC Press, Inc., Boca Raton, Fla.

124. Kierszenbaum, F., and M. D. Sztein. 1990. Mechanisms underlying immunosuppression induced by Trypanosoma cruzi. Parasitol. Today 6:261-264.

125. Kirchhof, L. V. 1989. Is Trypanosoma cruzi a new threat to our blood supply? Ann. Intern. Med. 111:773-775.

126. Kirchhof, L. V. 1992. Perspectives on Chagas' disease in Latin America and United States, p. 219-226. In D. H. Walker (ed.), Global medicine: current status and directions for the twentyfirst century. Springer Verlag, New York.

127. Kirchhof, L. V., A. A. Gam, and F. C. Gilliam. 1987. American trypanosomiasis (Chagas' disease) in Central American immigrants. Am. J. Med. 82:915-920.

128. Kirchhof, L. V., A. A. Gam, R. D. Gusmao, R. S. Goldsmith, J. M. Rezende, and A. Rassi. 1987. Increased specificity of serodiagnosis of Chagas' disease by detection of antibody to the 72- and 90-kilodalton glycoproteins of Trypanosoma cruzi. J. Infect. Dis. 155:561-564.

129. Kirchhoff, L. V., and F. A. Neva. 1985. Chagas' disease in Latin American immigrants. JAMA 254:3058-3060.

130. Koeberle, F. 1956. Die Chagaskrankheit, eine Eikromberg der neurorvegetativen periphene. Wien Klin. Wochenschr. 68: 333-339.

131. Koeberle, F. 1960. Muscular hypertrophy in Chagasic megaesophagus. Rev. Goiana Med. 6:147-153.

132. Koeberle, F. 1963. Patogenia do megaesofago brasileiro e europeu. Rev. Goiana Med. 9:79-116.

133. Koeberle, F. 1968. Chagas' disease and Chagas' syndromes: the pathology of American trypanosomiasis. Adv. Parasitol. 6:63-116.

134. Kohl, S., L. K. Pickering, L. S. Frankel, and R. G. Yaeger. 1982. Reactivation of Chagas' disease during therapy of acute lymphocytic leukemia. Cancer 50:827-828.

135. Krieger, M. A., E. Almeida, W. Oelemann, J. J. Lafaille, J. B. Pereira, H. Krieger, M. R. Carvalho, and S. Goldenberg. 1992. Use of recombinant antigens for the accurate immunodiagnosis of Chagas' disease. Am. J. Trop. Med. Hyg. 46:427-434.

136. Laranja, F. S., E. Dias, G. Nobrego, and A. Marinda. 1956. Chagas' disease-a clinical, epidemiologic and pathologic study. Circulation 14:1035-1060.

137. Leiguarda, R., A. Roncoroni, A. L. Tartuto, L. Jost, $M$. Berthier, M. Noguef, and H. Freiliji. 1990. Acute CNS in immunosuppressed patients. Neurology 40:850-851.

138. Libby, P., J. Alroy, and M. E. A. Pereira. 1986. A neuraminidase from Trypanosoma cruzi removes sialic acid from the surface of mammalian myocardial and endothelial cells. J. Clin. Invest. 77:127-135.

139. Libby, P., S. J. C. Warner, and G. B. Friedman. 1988. Interleukin 1: a mitogen for human vascular smooth muscle cells that induces the release of growth-inhibitory prostanoids. J. Clin. Invest. 81:487-498.

140. Libow, L. F., V. P. Beltrani, D. N. Silvers, and M. E. Grossman. 1991. Post-cardiac transplant reactivation of Chagas' disease diagnosed by skin biopsy. Cutis 48:37-40.

141. Long, R., A. Bishop, A. Barnes, R. H. Albuquerque, D. J. O'Shaughnessy, G. P. McGregor, R. Bannister, J. M. Polak, and S. P. Bloom. 1980. Neuronal and hormonal peptides in rectal biopsy specimens from patients with Chagas' disease and chronic autonomic failure. Lancet i:559-562.

142. Lopes, E., W. Tafuri, and E. Chapadeiro. 1969. Estudo morfologico e quantitativo dos nucleos dorsal do vago e hipoglosso em Chagasicos cronicos com e sem megaesofago. Rev. Inst. Med. Trop. Sao Paulo 11:123-129.

143. Losavio, A., M. C. Jones, O. P. Sanz, G. Mirkin, S. M. Gonzales-Cappa, S. Muchnick, and R. Sica. 1989. A sequential study of the peripheral nervous system involvement in experimental Chagas' disease. Am. J. Trop. Med. Hyg. 41:539-549.

144. Low, M. G. 1987. Biochemistry of the glycosyl-phosphatidylinositol membrane protein anchors. Biochem. J. 244:1-13.

145. Macedo, J., U. G. Meneghelli, R. B. Oliveira, R. A. Godoy, L. E. A. Troncon, and R. O. Dantas. 1986. Effect of CCK-OP and intraduodenal administration of essential amino acids on intraluminal pressures of sigmoid and rectum in patients with chagasic megacolon. Dig. Dis. Sci. 31:145-150.

146. Machado, A. B., C. R. Machado, and M. V. Gomez. 1978. Trypanosoma cruzi: acetylcholine content and cholinergic innervation of the heart in rats. Exp. Parasitol. 47:107-115.

147. Machado, A. B. M., G. R. S. Machado, and C. G. Gomez. 1975. Depletion of heart norepinephrine in experimental acute myocarditis caused by Trypanosoma cruzi. Experientia 31:12021203.

148. Maguire, J. H., R. Hof, I. Sherlock, A. C. Guimaraes, A. C. Sleigh, N. B. Ramos, K. E. Mott, and T. H. Weller. 1987. Cardiac morbidity and mortality due to Chagas' disease: prospective electrocardiographic study of a Brazilian community. Circulation 75:1140-1145.

149. Marin-Neto, J. A., P. Marzullo, C. Marcassa, R. L. Gallo, B. C. Marciel, R. C. Bellina, and A. L'Abbate. 1990. Perfusion defects detected by thallium-201 scintigraphy in Chagas' heart disease. J. Am. Coll. Cardiol. 15:240A.

150. Marr, J. J., and R. Docampo. 1986. Chemotherapy for Chagas' disease: a perspective of current therapy and consideration for future research. Rev. Infect. Dis. 8:884-903.

151. McCabe, R. E., and B. T. Mullins. 1990. Failure of Trypanosoma cruzi to trigger the respiratory burst of activated macrophages. Mechanism for immune evasion and importance of oxygen-independent killing. J. Immunol. 144:2384-2388.

152. McCormick, T. S., and E. C. Rowland. 1989. Trypanosoma cruzi: cross-reactive anti heart autoantibodies produced during infection in mice. Exp. Parasitol. 69:393-401.

153. Meneghelli, U. 1970. Estudos farmacologicos no megacolon chagasico. Rev. Goiana Med. 14:61-67.

154. Meneghelli, U. 1985. Chagas' disease: a model of denervation in the study of digestive tract motility. Braz. J. Med. Biol. Res. 55:255-264.

155. Meneghelli, U., R. Godoy, and R. Oliviera. 1983. Effects of Pentagastrin on the motor activity of the dilated and nondilated sigmoid and rectum in Chagas' disease. Digestion 27:152-158.

156. Meneghelli, U., and L. Reis. 1967. Estudas sobre de metabolismo dos hidratos de carbono na molestia de Chagas. Rev. Assoc. Bras. Med. 13:3-10.

157. Meneghelli, U., C. Vieria, W. Padovan, and R. Godoy. 1971. O teste da d-xylose na forma cronica da molestia de Chagas. Arch. Gastroenterol. 8:191-198.

158. Mesri, E. A., G. Levitus, M. Hontebeyrie-Joskowicz, G. Dighiero, M. H. Van Regenmortel, and M. J. Levin. 1990. Major Trypanosoma cruzi antigenic determinant in Chagas' heart disease shares homology with the systemic lupus erythematosus ribosomal P protein epitope. J. Clin. Microbiol. 28:12191224.

159. Molina, H. A., and F. Kierszenbaum. 1989. Eosinophil activation in acute and chronic chagasic myocardial lesions and deposition of toxic eosinophil granule proteins on heart myofibers. J. Parasitol. 75:129-133.

160. Moncayo, A., and A. O. Luquetti. 1990. Multicentre double blind study for evaluation of Trypanosoma cruzi defined antigens as diagnostic reagents. Mem. Inst. Oswaldo Cruz Rio J. 85:489-495.

161. Monteverde, D. A., A. L. Taratuto, and N. Lucatelli. 1976. Meningoencefalitis chagásica aguda en pacientes inmuno- 
suprimidos. Rev. Neurol. Arg. 2:260-266.

162. Morales-Filho, J., O. Kohatsu, and A. Bettarello. 1986. Pressao basal do esfincter inferior do esafogo na doenca de Chagas: megaesofago na forma indeterminada. Rev. Assoc. Med. Bras. 32:51-53.

163. Moreira, M., M. Rezende, and L. Rassik. 1970. Estudo da motilidade do colo transverso nas esofagocoloplastias. Rev. Goiana Med. 16:522.

164. Morris, S. A., S. Barr, L. Weiss, H. Tanowitz, M. Wittner, and J. P. Bilezikian. 1991. Myocardial $\beta$-adrenergic adenylate cyclase complex in a canine model of chagasic cardiomyopathy. Circ. Res. 69:185-195.

165. Morris, S. A., J. P. Bilezikian, V. Hatcher, L. M. Weiss, H. B. Tanowitz, and M. Wittner. 1989. Tryapanosoma cruzi: infection of cultured human endothelial cells alters inositol phosphate synthesis. Exp. Parasitol. 69:330-339.

166. Morris, S. A., J. P. Bilezikian, H. B. Tanowitz, and M. Wittner. 1987. Infection of $\mathrm{L}_{6} \mathrm{E}_{9}$ myoblasts with Trypanosoma cruzi alters adenylate cyclase activity and guanine nucleotide binding proteins. J. Cell. Physiol. 133:64-71.

167. Morris, S. A., V. Hatcher, J. P. Bilezikian, H. B. Tanowitz, and M. Wittner. 1988. Alterations in intracellular calcium following infection of human endothelial cells with Trypanosoma cruzi. Mol. Biochem. Parasitol. 29:213-221.

168. Morris, S. A., H. B. Tanowitz, S. M. Factor, J. P. Bilezikian, and $M$. Wittner. 1988. Myocardial adenylate cyclase activity in acute murine Chagas' disease. Circ. Res. 62:800-810.

169. Morris, S. A., H. B. Tanowitz, M. Makman, V. B. Hatcher, J. P. Bilezikian, and M. Wittner. 1992. Trypanosoma cruzi: alteration of CAMP metabolism following infection of human endothelial cells. Exp. Parasitol. 74:69-76.

170. Morris, S. A., L. M. Weiss, S. M. Factor, J. P. Bilezikian, H. B. Tanowitz, and M. Wittner. 1989. Verapamil ameliorates clinical, pathological and biochemical manifestations of experimental chagasic cardiomyopathy in mice. J. Am. Coll. Cardiol. 14:782-789.

171. Morris, S. A., M. Wittner, L. Weiss, V. B. Hatcher, H. B Tanowitz, J. P. Bilezikian, and P. B. Gordon. 1990. Extracellular matrix derived from Trypanosoma cruzi infected endothelial cells directs cellular phenotypic expression. J. Cell. Physiol. 145:340-346.

172. Mortatti, R. C., L. C. Maia, A. V. De Oliveira, and M. E. Munk. 1990. Immunopathology of experimental Chagas' disease: binding of $\mathrm{T}$ cells to Trypanosoma cruzi-infected heart tissue. Infect. Immun. 58:3588-3593.

173. Moser, D. R., L. V. Kirchhoff, and J. E. Donelson. 1989. Detection of Trypanosoma cruzi by polymerase chain reaction gene amplification. J. Clin. Microbiol. 27:1744-1749.

174. Munoz-Fernandez, M. A., M. A. Fernandez, and M. Fresno. 1992. Synergism between tumor necrosis factor-alpha and interferon-gamma on macrophage activation for the killing of intracellular Trypanosoma cruzi through a nitric oxide-dependent mechanism. Eur. J. Immunol. 22:301-307.

175. Nachman, R. L., K. A. Hajjar, R. L. Silverstein, and C. A. Dinarello. 1986. Interleukin 1 induces endothelial cell synthesis of plasminogen activator inhibitor. J. Exp. Med. 163:15951600.

176. Navin, T. R., R. R. Roberto, and D. D. Juranek. 1985. Human and sylvatic Trypanosoma cruzi infection in California. Am. J. Public Health 75:366-369.

177. Nickerson, P., P. Orr, M. L. Schroeder, L. Sekla, and J. B. Johnston. 1989. Transfusion-associated Trypanosoma cruzi infection in a non-endemic area. Ann. Intern. Med. 111:851-853.

178. Okumura, M., A. Correa-Neto, and A. C. Silva. 1962. Contribuicao para o estudo da patogenia das lesoes vasculares na doenca de Chagas experimental em camundongos branco. Rev. Paul. Med. 61:265-266.

179. Okumura, M., T. De Brito, L. H. P. Silva, and A Correa-Neto. 1960. The pathology of experimental Chagas' disease in mice. I. Digestive tract changes with a reference to necrotising arteritis. Rev. Inst. Med. Trop. Sao Paulo 2:17-28.

180. Oliveira, J. S. 1985. A natural human model of intrinsic heart nervous system denervation: Chagas' cardiopathy. Am. Heart
J. 110:1092-1098

181. Oliveira, J. S. M., R. R. C. Correa De Araujo, M. A. Navarro, and G. Muccillo. 1983. Cardiac thrombosis and thromboembolism in chronic Chagas' heart disease. Am. J. Cardiol. 52:147151.

182. Oliveira, J. S. M., J. A. M. De Oliveira, U. Frederigue, and E. C. L. Filho. 1981. Apical aneurysm of Chagas' heart disease. Br. Heart J. 46:432-437.

183. Oliveira, J. S. M., J. C. dos Santos, G. Muccillo, and A. L. Ferreira. 1985. Increased capacity of the coronary arteries in chronic Chagas' heart disease: further support for the neurogenic pathogenesis concept. Am. Heart J. 109:304-308.

184. Oliveira, R., U. Meneghelli, R. Godoy, R. O. Dantas, and W. Padovan. 1983. Abnormalities of interdigestive motility of the small intestine in patients with Chagas' disease. Dig. Dis. Sci. 28:294-299.

185. Orr, G. A., H. B. Tanowitz, and M. Wittner. 1992. Trypanosoma cruzi: stage expression of calmodulin-binding proteins. Exp. Parasitol. 74:127-133.

186. Ortega-Barria, E., and M. E. A. Pereira. 1991. A novel T. cruzi heparin-binding protein promotes fibroblast adhesion and penetration of engineered bacteria and trypanosomes into mammalian cells. Cell 67:411-421.

187. Ouaissi, M. A., A. Taibi, J. Cornette, P. Velge, B. Marty, M. Loyens, M. Esteva, F. S. Rizvi, and A. Capron. 1990. Characterization of major surface and excretory-secretory immunogens of Trypanosoma cruzi trypomastigotes and identification of potential protective antigen. Parasitology 100:115-124.

188. Oz, H. S., M. Wittner, H. B. Tanowitz, J. P. Bilezikian, M. Saxon, and S. A. Morris. 1992. Trypanosoma cruzi: mechanisms of calcium homeostasis. Exp. Parasitol. 74:390-399.

189. Padovan, W., R. Godoy, U. Meneghelli, R. O. Dantas, R. B. Oliveira, and L. E. A. Troncon. 1982. Acid and pepsin secretion in chronic Chagas' disease patients in response to graded doses of pentagastrin and pentagastrin plus bethanacol. Digestion 23:48-56.

190. Padovan, W., R. A. Godoy, R. O. Dantas, U. G. Meneghelli, R. B. Oliveira, and L. E. A. Troncon. 1980. Lower esophageal sphincter response to pentagastrin in chagasic patients with megaesophagus and megacolon. Gut 21:85-90.

191. Paula-Costa, M. D., and J. M. Rezende. 1978. Pressão basal do esfíncter inferior do esôfago no megaesôfago chagásico. Rev. Assoc. Med. Bras. 24:269-272.

192. Pereira, M. E. A. 1983. A developmentally regulated neuraminidase activity in Trypanosoma cruzi. Science 219:1444-1446.

193. Pereira, M. E. A. 1990 . Cell biology of Trypanosoma cruzi, p. 64-78. In D. Wyler (ed.), Modern parasite biology. W. H. Freeman and Co., New York.

194. Pereira-Baretto, A. C. P., C. Mady, E. Arteaga-Fernandez, N. Stolf, E. A. Lopes, M. de Lourdes Higuchi, G. Bellotti, and F. Pileggi. 1986. Right ventricular endomyocardial biopsy in chronic Chagas' disease. Am. Heart J. 111:307-312.

195. Pessoa, J. 1967. Behavior of the cardia in disease of the esophagus in Chagas disease. Rev. Bras. Med. 24:428-441.

196. Petry, K., and H. Eisen. 1989. Chagas' disease: a model for the study of auto immune diseases. Parasitol. Today 5:111-116.

197. Petry, K., E. Nudelman, H. Eisen, and S. Hakomori. 1988. Sulfated lipids represent common antigens on the surface of Trypanosoma cruzi and mammalian tissues. Mol. Biochem. Parasitol. 30:113-121.

198. Petry, K., P. Voisin, T. Baltz, and J. Labouesse. 1987. Epitopes common to trypanosomes ( $T$. cruzi, $T$. dionissi and $T$. vespertilonis (Schizotrypanum)): astrocytes and neurons. J. Neuroimmunol. 16:237-252.

199. Pimenta, J., M. Miranda, and C. B. Pereira. 1983. Electrophysiologic findings in long-term asymptomatic Chagasic individuals. Am. Heart J. 106:374-380.

200. Pinott, H. W., A. Raia, A. Correa-Netto, and A. Bettarello. 1968. The sphincter of the lower esophagus in various stages of megaesophagus provoked by Chagas' disease. Arq. Gastroenterol. 5:51-58.

201. Prata, A., and G. Porto. 1966. Biopsia de musculo na doenca de Chagas. Rev. Inst. Med. Trop. Sao Paulo 8:193-196. 
202. Prioli, R. P., J. S. Mejia, and M. E. A. Pereira. 1991. On the interaction of Trypanosoma cruzi neuraminidase and human lipoproteins. Eur. J. Epidemiol. 7:344-348.

203. Prioli, R., I. Rosenberg, and M. E. A. Pereira. 1990. High and low density lipoproteins enhance infection of Trypanosoma cruzi in vitro. Mol. Biochem. Parasitol. 38:191-198.

204. Raizman, R., J. Rezende, and F. A. Neva. 1980. A clinical trial with pre- and post-treatment manometry comparing pneumatic dilation with bouginage for treatment of Chagas megaesophagus. Am. J. Gastroenterol. 74:405-409.

205. Rangel-Aldao, R., O. Allende, F. Treona, R. Piros, D. Henriquez, and P. Martos. 1987. Possible role of cAMP in the differentiation of Trypanosoma cruzi. Mol. Biochem. Parasitol. 22:39-43.

206. Rassi, A. 1979. Clínica: fase aguda, p. 249-264. In Z. Brener and Z. A. Andrade (ed.), Trypanosoma cruzi e Doneça de Chagas. Guanabara Koogan, Rio de Janeiro, Brazil.

207. Reed, S. G. 1988. In vivo administration of recombinant IFN-gamma induces macrophage activation and prevents acute disease, immune suppression, and death in experimental Trypanosoma cruzi infections. J. Immunol. 140:4342-4347.

208. Reed, S. G., K. H. Grabstein, D. L. Pihl, and P. J. Morrissey. 1990. Recombinant granulocyte-macrophage colony-stimulating factor restores deficient immune responses in mice with chronic Trypanosoma cruzi infections. J. Immunol. 145:1564 1570.

209. Renny, A., W. Snape, E. Sun, R. London, and S. Cohen. 1983. Role of cholecystokinin in the gastrocolic response to a fat meal. Gastroenterology 85:17-21.

210. Reyes, M. B., M. Lorca, P. Munoz, and A. C. Frasch. 1990 Fetal IgG specificities against Trypanosoma cruzi antigens in infected newborns. Proc. Natl. Acad. Sci. USA 87:2846-2850.

211. Rezende, J. M. 1962. The endemic South American megaesophagus, p. 69-74. In F. Ingelfinger and G. Siffert (ed.), 2nd World Congress of Gastroenterology, vol. I. S. Karger, Basel.

212. Rezende, J. 1984. The digestive tract in Chagas' disease. Mem. Inst. Oswaldo Cruz Rio J. 79(Suppl.):97-106.

213. Rezende, J., M. J. Rosa, M. Vaz, S. Andrade, J. D. Porta, J. Neves-Neto, and J. A. Ximenas. 1985. Endoscopy in megaesophagus. Prospective study of 600 cases. Arq. Gastroenterol. Sao Paulo 22:53-66.

214. Ribeiro dos Santos, R., and L. Hudson. 1981. Denervation and the immune response in mice infected with Trypanosoma cruzi. Clin. Exp. Immunol. 44:349-354.

215. Ribeiro dos Santos, R., M. A. Rossi, J. L. Kaus, J. S. Silva, W. Savino, and J. Mengel. 1992. Anti-CD4 abrogates rejection and reestablishes long-term tolerance to syngeneic newborn hearts grafted in mice chronically infected with Trypanosoma cruzi. J. Exp. Med. 175:29-39.

216. Rimoldi, M. T., A. J. Tenner, D. A. Bobak, and K. A. Joiner. 1989. Complement component Clq enhances invasion of human mononuclear phagocytes and fibroblasts by Trypanosoma cruzi trypomastigotes. J. Clin. Invest. 84:1982-1989.

217. Rivero, I., M. Moravenik, J. Morales, M. Gomez, and J. M. De Rosas. 1974. Chagas' disease-another hazard in acute leukemia. N. Engl. J. Med. 290:285.

218. Rizzo, L. V., E. Cunha-Neto, and A. R. Teixeira. 1989. Autoimmunity in Chagas' disease: specific inhibition of reactivity of $\mathrm{CD}^{+} \mathrm{T}$ cells against myosin in mice chronically infected with Trypanosoma cruzi. Infect. Immun. 57:2640-2644.

219. Rocha, A., H. Ameid, V. Texeira, and A. Silva. 1985. Prevelance of cholelithiasis in autopsies of patients with chronic Chagas' disease in the mining triangle. Correlation with megaesophagus, megacolon and cardiac insufficiency. Arq. Gastroenterol. 22:3-6.

220. Rosemberg, S., C. J. Chaves, M. L. Higuchi, M. B. S. Lopes, L. H. M. Castro, and L. R. Machado. 1991. Fatal chagasic meningoencephalitis caused by reactivation of Trypanosoma cruzi infection in a patient with AIDS. Neurology 42:640-642.

221. Rosenbaum, M. B. 1965. Chagasic myocarditis. Prog. Cardiovasc. Dis. 7:199-224.

222. Rosenberg, I. A., R. P. Prioli, J. S. Mejia, and M. E. A. Pereira. 1991. Differential expression of Trypanosoma cruzi neuramin- idase in intra- and extracellular trypomastigotes. Infect. Immun. 59:464-466.

223. Rossi, M. A. 1990 . Microvascular changes as a cause of chronic cardiomyopathy in Chagas' disease. Am. Heart J. 120:233-236.

224. Rowin, K. S., H. B. Tanowitz, M. Wittner, H. T. Nyguen, and B. Nadal-Ginard. 1983. Inhibition of muscle differentiation by Trypanosoma cruzi. Proc. Natl. Acad. Sci. USA 80:6390-6394.

225. Sadigursky, M., A. M. Acosta, and C. A. Santos-Buch. 1981. Muscle sarcoplasmic reticulum antigen shared by a Trypanosoma cruzi clone. Am. J. Trop. Med. Hyg. 31:934-941.

226. Said, G. M., M. Joskowicz, A. A. Barroira, and H. Eisen. 1985. Neuropathy associated with experimental Chagas' disease. Ann. Neurol. 18:676-683.

227. Santos-Buch, C. A., and A. M. Acosta. 1985. Pathology of Chagas' disease, p. 145-183. In I. Tizard (ed.), Immunology and pathogenesis of trypanosomiasis. CRC Press, Inc., Boca Raton, Fla.

228. Santos-Buch, C. A., A. M. Acosta, H. J. Zweerink, M. Sadigursky, O. F. Andersen, B. F. von Kreuter, C. Brodskyn, C. Sadigursky, and R. Cody. 1985. Primary muscle disease: definition of a $25-\mathrm{kDa}$ polypeptide myopathic specific Chagas' antigen. Clin. Immunol. Immunopathol. 37:334-350.

229. Schenkman, S., N. W. Andrews, V. Nussenzweig, and E. S. Robbins. 1988. Trypanosoma cruzi invade a mammalian epithelial cell in a polarized manner. Cell 55:157-165.

230. Schenkman, S., L. P. de Carvalho, and V. Nussenzweig. 1992. Trypanosoma cruzi trans-sialidase and neuraminidase activities can be mediated by the same enzymes. J. Exp. Med. 175:567-575.

231. Schenkman, S., M. S. Jiang, G. W. Hart, and V. Nussenzweig. 1991. A novel cell surface trans-sialidase of Trypanosoma cruzi generates a stage-specific epitope required for invasion of mammalian cells. Cell 65:1117-1125.

232. Schenkman, S., E. S. Robbins, and V. Nussenzweig. 1991. Attachment of Trypanosoma cruzi to mammalian cells requires parasite energy, and invasion can be independent of the target cell cytoskeleton. Infect. Immun. 59:645-654.

233. Schenkman, S. N., N. Yoshida, and M. L. Cardoso de Almeida. 1988. Glycophasphatidyl inositol-anchored proteins in metacyclic trypomastigotes of Trypanosoma cruzi. Mol. Biochem. Parasitol. 29:141-152.

234. Schumnis, G. A. 1991. Trypanosoma cruzi, the etiologic agent of Chagas' disease: status in the blood supply in endemic and non-endemic countries. Transfusion 31:547-557.

235. Sher, A., S. Hieny, and K. Joiner. 1986. Evasion of the alternative complement pathway by meta cyclic trypomastigotes of Trypanosoma cruzi: dependence on the developmentally regulated synthesis of surface protein and $\mathrm{N}$-linked carbohydrate. J. Immunol. 137:2961-2967.

236. Sher, A., and D. Snary. 1982. Specific inhibition of the morphogenesis of Trypanosoma cruzi by a monoclonal antibody. Nature (London) 300:639-640.

237. Shikanai-Yasuda, M. A., M. H. Lopes, J. E. Tolezano, E. Umezawa, V. Amato Neto, A. C. Pereira Barreto, Y. Higaki, A. A. B. Moreira, G. Funayama, A. A. Barone, A. Duarte, V. Odone, G. C. Cerri, M. Sato, D. Possi, and M. Shiroma. 1990. Doença de Chagas aguda: vias de transmissío, aspectos clínicos e resposta à terapêutica específica em casos diagnosticados em um centro urbano. Rev. Inst. Med. Trop. Sao Paulo 32: 16-27.

238. Silva, J. S., P. J. Morrissey, K. H. Grabstein, K. M. Mohler, D. Anderson, and S. G. Reed. 1992. Interleukin 10 and interferon $\gamma$ regulation of experimental Trypanosoma cruzi infection. J. Exp. Med. 175:169-174.

239. Silveria, G. 1976. Chagas' disease of the colon. Br. J. Surg. 63:831-835.

240. Snape, W., G. Cason, and S. Cohen. 1977. Human colonic myoelective activity in response to prostigmin and other gastrointestinal hormones. Am. J. Dig. Dis. 22:881-887.

241. Snary, D., J. Flint, J. N. Wood, M. T. Scott, M. D. Scott, M. D. Chapman, J. Dodd, T. M. Jessel, and M. A. Miles. 1983. A monoclonal antibody with specificity for Trypanosoma cruzi central and peripheral neurons and glia. Clin. Exp. Immunol. 
54:617-624.

242. Soergel, K., F. Zobralske, and J. Amberg. 1964. Presbyesophagus. Esophageal motility in nonagenarians. J. Clin. Invest. 43:1472-1479.

243. Sterin-Borda, L., G. Gorelik, A. Genaro, J. C. Goin, and E. S. Borda. 1990. Human chagasic IgG interacting with lymphocyte neurotransmitter receptor signal transduction. FASEB J. 4:1661-1667.

244. Stolf, N. A. G., L. Higushi, E. Bocchi, G. Bellotti, J. O. Costa Auler, D. Uip, V. Amato Neto, F. Pileggi, and A. D. Jatene. 1987. Heart transplantation in patients with Chagas' disease cardiomyopathy. Heart Transplant. 6:307-312.

245. Sturm, N. R., W. Degrave, C. Morel, and L. Simpson. 1989. Sensitive detection and schizodeme classification of Trypanosoma cruzi cells by amplification of kinetoplast minicircle DNA sequences: use in diagnosis of Chagas' disease. Mol. Biochem. Parasitol. 33:205-214.

246. Szarfman, A., V. P. Terranova, S. L. Renard, J. Foidart, J. Lima, J. Scheinman, and J. Martin. 1987. Antibodies to laminin in Chagas' disease. J. Exp. Med. 155:1161-1171.

247. Tanaka, Y., C. Kiyotaki, H. B. Tanowitz, and B. R. Bloom. 1987. Reconstitution of a variant macrophage cell line defective in oxygen metabolism with an $\mathrm{H}_{2} \mathrm{O}_{2}$ generating system. Proc. Natl. Acad. Sci. USA 79:2584-2588.

248. Tanowitz, H. B., C. Brosnan, D. Gustamachio, G. Baron, C. Raventos-Suarez, M. Bornstein, and M. Wittner. 1982. Infection of organotypic cultures of spinal cord and dorsal root ganglia with Trypanosoma cruzi. Am. J. Trop. Med. Hyg. 31:1090-1097.

249. Tanowitz, H. B., E. R. Burns, A. K. Sinha, N. N. Kahn, S. A. Morris, S. M. Factor, V. B. Hatcher, J. P. Bilezikian, S. G. Baum, and M. Wittner. 1990. Enhanced platelet adherence and aggregation in Chagas' disease: a potential pathogenic mechanism for cardiomyopathy. Am. J. Trop. Med. Hyg. 43:274-281.

250. Tanowitz, H. B., P. Davies, S. M. Factor, T. Minase, A. Herkowitz, and M. Wittner. 1981. Trypanosoma cruzi: choline acetyltransferase activity in tissues of susceptible and resistant mice infected with the Brazil strain. Exp. Parasitol. 51:269 278.

251. Tanowitz, H. B., P. Davies, and M. Wittner. 1983. Alterations in acetylcholine receptors in experimental Chagas' disease. J. Infect. Dis. 147:460-466.

252. Tanowitz, H. B., J. P. Gumprecht, D. Spurr, T. M. Calderon, M. C. Ventura, C. Raventos-Suarez, S. Kellie, S. M. Factor, V. B. Hatcher, M. Wittner, and J. W. Berman. 1992. Cytokine gene expression of endothelial cells infected wtih Trypanosoma cruzi. J. Infect. Dis. 166:598-603.

253. Tanowitz, H. B., S. A. Morris, S. A. Factor, L. M. Weiss, and M. Wittner. 1992. Parasitic diseases of the heart I: acute and chronic Chagas' disease. Cardiovasc. Pathol. 1:7-15.

254. Tanowitz, H. B., S. A. Morris, L. M. Weiss, J. P. Bilezikian, S. M. Factor, and M. Wittner. 1989. Effect of verapamil on the development of chronic experimental Chagas' disease. Am. J. Trop. Med. Hyg. 41:643-649.

255. Tanowitz, H. B., D. Simon, J. P. Gumprecht, L. M. Weiss, and M. Wittner. 1990. Gastrointestinal manifestations of Chagas' disease, p. 56-75. In V. K. Rustgi (ed.), Gastrointestinal infections in the tropics. S. Karger, Basel.

256. Tanowitz, H. B., M. Wittner, Y. Kress, and B. R. Bloom. 1975. Studies of in vitro infection by Trypanosoma cruzi. Am. J. Trop. Med. Hyg. 24:25-33.

257. Tarleton, R. L. 1988. Trypanosoma cruzi-induced suppression of IL-2 production. I. Evidence for the presence of IL-2 producing cell. J. Immunol. 140:2763-2768.

258. Tarleton, R. L. 1988. Tumour necrosis factor (cachetin) production during experimental Chagas' disease. Clin. Exp. Immunol. 73:186-190.

259. Tarleton, R. L. 1990 . Depletion of $\mathrm{CD}^{+} \mathrm{T}$ cells increases susceptibility and reverses vaccine-induced immunity in mice infected with Trypanosoma cruzi. J. Immunol. 144:717-724.

260. Tarleton, R. L. 1991. Regulation of immunity in Trypanosoma cruzi infection. Exp. Parasitol. 73:106-109.

261. Tarleton, R. L., B. H. Koller, A. Latour, and M. Postan. 1992.
Susceptibility of $\beta_{2}$-microglobulin-deficient mice to Trypanosoma cruzi infection. Nature (London) 356:338-340.

262. Tarleton, R. L., and R. E. Kuhn. 1984. Restoration of in vitro immune responses of spleen cells from mice infected with Trypanosoma cruzi by supernatants containing interleukin 2 . J. Immunol. 133:1570-1575.

263. Tarleton, R. L., and G. S. Nabors. 1991. Regulation of cytokine production in Chagas' disease, p. 15-30. In C. C. Wang (ed.), Molecular and immunological aspects of parasitism. American Association for the Advancement of Science, Washington, D.C.

264. Teixeira, A. R. L., J. C. Cordova, I. Souto Maior, and E. Solorzano. 1990. Chagas' disease: lymphoma growth in rabbits treated with benznidazole. Am. J. Trop. Med. Hyg. 43:146158.

265. Teixeira, A. R. L., R. Silva, E. Cunha Neto, J. M. Santana, and L. V. Rizzo. 1990. Malignant, non-Hodgkin's lymphomas in Trypanosoma cruzi-infected rabbits treated with nitroarenes. J. Comp. Pathol. 103:37-48.

266. Teixeira, A. R. L., G. Teixeira, V. Macedo, and A. Prata. 1978. Trypanosoma cruzi sensitized T-lymphocyte mediated ${ }^{51} \mathrm{Cr}$ release from human heart cells in Chagas' disease. Am. J. Trop. Med. Hyg. 27:1097-1107.

267. Teixeira, A. R. L., M. L. Teixeira, and C. A. Santos-Buch. 1974. The immunology of experimental Chagas' disease. IV. Production of lesions in rabbits similar to those of chronic Chagas' disease in man. Am. J. Pathol. 80:163-180.

268. Tellez-Inon, M. T., R. M. Ulloa, M. Torruela, and H. N. Torres. 1985. Calmodulin and calmodulin-dependent cyclic AMP phosphodiesterase activity in Trypanosoma cruzi. Mol. Biochem. Parasitol. 14:143-153.

269. Ternynck, T., C. Bleux, J. Gregoire, S. Avrameas, and C. Kanellopoulos-Langevin. 1990. Comparison between autoantibodies arising during Trypanosoma cruzi infection in mice and natural autoantibodies. J. Immunol. 144:1504-1511.

270. Torres, C. M. 1958 . Arteriolosclerose das finas ramificacoes do miocardio (coronarite chagasica) e miocitolise focal do miocardio na cardiopatia chagasica cronica. Hospital 54:597-610.

271. Troncon, L., R. Oliveira, U. G. Meneghelli, R. O. Dantas, and R. A. Godoy. 1984. Fasting and food stimulated plasma gastrin levels in chronic Chagas' disease. Digestion 29:171-176.

272. Troncon, L., J. Rezendi, and N. Iazigi. 1988. Duodenogastric reflex in Chagas' disease. Dig. Dis. Sci. 33:1260-1264.

273. Van Voorhis, W. C. 1992. Coculture of human peripheral blood mononuclear cells with Trypanosoma cruzi leads to proliferation of lymphocytes and cytokine production. J. Immunol. 148:239-248.

274. Van Voorhis, W. C., L. Schlekewy, and H. L. Trong. 1991. Molecular mimicry by Trypanosoma cruzi: the F1-160 epitope that mimics mammalian nerve can be mapped to a 12-aminoacid peptide. Proc. Natl. Acad. Sci. USA 88:5993-5997.

275. Vercesi, A. E., M. E. Hoffman, C. F. Bernardes, and R. Docampo. 1991. Regulation of intracellular calcium homeostasis in Trypanosoma cruzi. Effects of calmidazolium and trifluoperazine. Cell Calcium 12:361-369.

276. Vieira, C., and R. Godoy. 1963. Resposta motora do esotago nao ectasico a agenes colinergicos na molestia de Chagas. Rev. Goiana Med. 9:21-28.

277. Vieira, C., R. Godoy, and C. Carril. 1964. Hypersensitivitiy of the large colon to cholinergic agents in patients with Chagas' disease and megacolon. Rev. Bras. Gastroenterol. 16:41.

278. Villanova, M., U. Meneghelli, and R. O. Dantas. 1987. Gallbladder motor function in chagasic patients with megacolon and/or megaesophagus. Digestion 36:189-194.

279. Yaeger, R. G. 1988. The prevalence of Trypanosoma cruzi infection in armadillos collected at a site near New Orleans, Louisiana. Am. J. Trop. Med. Hyg. 38:323-326.

280. Weinstein, C., and J. J. Fenoglio. 1987. Myocarditis. Hum. Pathol. 18:613-618.

281. Williams, G. D., L. G. Adams, and R. G. Yaeger. 1977. Naturally occurring trypanosomiasis (Chagas' disease) in dogs. J. Am. Vet. Med. Assoc. 171:171-177.

282. Wirth, J. J., F. Kierszenbaum, and A. Zlotnik. 1988. Effect of 
interleukin-4 on macrophage interaction with Trypanosoma cruzi. Comparison with interferon gamma. FASEB J. 2:A453.

283. Wood, J. N., L. Hudson, T. M. Jessell, and M. Yamamoto. 1982. A monoclonal antibody defining antigenic determinants on subpopulations of mammalian neurones and Trypanosoma cruzi parasites. Nature (London) 296:34-38.

284. Wyler, D. J., P. Libby, S. Prakash, R. P. Prioli, and M. E. A. Pereira. 1987. Elaboration by mammalian mesenchymal cells infected with Trypanosoma cruzi or a fibroblast-stimulating factor that may contribute to chagasic cardiomyopathy. Infect. Immun. 55:3188-3191.

285. Zicker, F., J. C. de Almeida Netto, E. M. S. Zicker, R. M. Oliveira, and P. G. Smith. 1990. Trypanosoma cruzi infection and electrocardiographic findings among active manual workers. A population-based study in central Brazil. Int. J. Epidemiol. 19:182-186. 